\title{
Roots and rhizomes of wild Asparagus: Nutritional composition, bioactivity and nanoencapsulation of the most potent extract
}

\author{
Khaoula Adouni ${ }^{\mathrm{a}, \mathrm{h}}$, Ana Júlio ${ }^{\mathrm{b}, \mathrm{c}}$, Celestino Santos-Buelga ${ }^{\mathrm{d}}$, Ana M. González-Paramás ${ }^{\mathrm{d}}$, \\ Patrícia Filipe $^{\mathrm{b}, \mathrm{c}}$, Patricia Rijo ${ }^{\mathrm{b}, \mathrm{e}}$, Sofia A. Costa Lima ${ }^{\mathrm{f}}$, Salette Reis ${ }^{\mathrm{f}}$, Ângela Fernandes ${ }^{g}$, \\ Isabel C.F.R. Ferreira ${ }^{g}$, Virginia Fernández-Ruiz ${ }^{\text {h }}$, Patricia Morales ${ }^{\text {h, }}$, Guido Flamini ${ }^{\mathrm{i}, \mathrm{j}}$, \\ Lotfi Achour ${ }^{a}$, Pedro Fonte ${ }^{\mathrm{k}, 1, \mathrm{~m}, \mathrm{n}}$
}

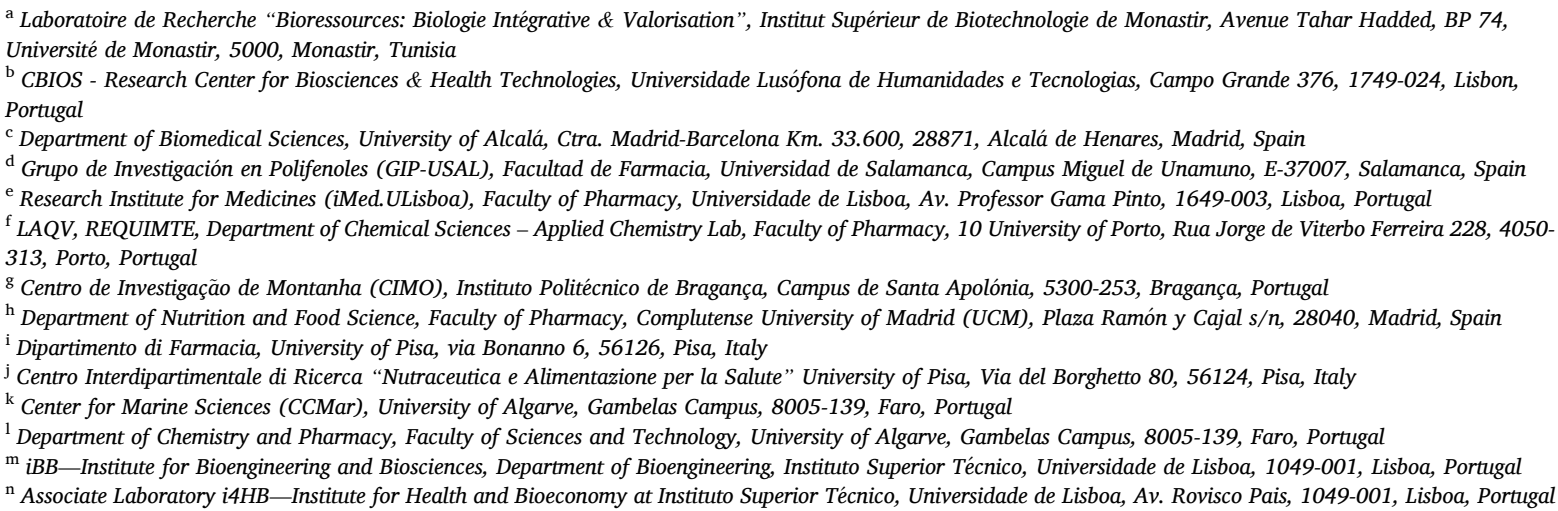

\section{A R T I C L E I N F O}

\section{Keywords:}

Asparagus stipularis

Nutritional composition

Antioxidant activity

Nanoparticles

PLGA

\begin{abstract}
A B S T R A C T
The nutritional composition and bioactive properties of roots and rhizomes of Asparagus stipularis were evaluated. Antioxidant activity of extracts obtained by infusion was evaluated using free radicals scavenging and reducing power methods. Porcine liver primary cell was used to check the hepatotoxicity of infusions. Results revealed that Asparagus samples are likely a source of nutrients, such as dietary fibre and essential fatty acids. HPLC-DAD-ESI/MS characterization of infusions allowed the identification and quantitation of 7 phenolic compounds, all hydroxycinnamoyl derivatives, with caffeic acid as the most abundant. Roots infusion contained the highest amounts of these compounds. It also exhibited the highest antioxidant activity in all assays, with $\mathrm{EC}_{50}$ values of $0.44 \pm 0.01,0.98 \pm 0.03$ and $0.64 \pm 0.01 \mathrm{mg} / \mathrm{mL}$ for DPPH, ABTS and FRAP assays, respectively, with no toxicity towards PLP2 primary cell cultures $\left(\mathrm{GI}_{50}>400 \mu \mathrm{g} / \mathrm{mL}\right)$. PLGA nanoparticles loaded with root extract were prepared using solvent-evaporation double emulsion method. Nanoparticles size was about $260 \mathrm{~nm}$ and a polydispersity index around 0.1 , with a zeta potential of about $-36 \mathrm{mV}$, as well as a good encapsulation efficiency of approximately 83\%. Their morphology was analysed by SEM and spherical polymeric nanoparticles with a smooth surface were observed. FTIR and DSC were also performed, which allowed corroborating the efficacy of the encapsulation and to confirm the production of a stable and robust system to load Asparagus extracts. The developed nanoparticles are expected to be used as delivery systems for bioactive compounds of $A$. stipularis and they could be used as an innovative dietary supplement.
\end{abstract}

\footnotetext{
* Corresponding author.

E-mail address: patricia.morales@farm.ucm.es (P. Morales).
} 


\section{Introduction}

Asparagus is a genus that belongs to the Liliaceae family and contains over 300 species widely diffused in the world continents (Kanno \& Yokoyama, 2011). Eastern civilizations have used Asparagus extracts as laxatives, stimulants, and diuretics for centuries (Fuentes-Alventosa et al., 2009). Furthermore, Greek medicine used Asparagus extracts as a tonic to cure many ailments, such as the rheumatic, cancer, rheumatic, liver, and kidney diseases (Pegiou et al., 2019). The genus Asparagus includes commercially important species, essentially $A$. officinalis L. and A. albus L., whereas the remaining species are poorly known, such as A. stipularis Forssk (Serairi-Beji et al., 2017). In Spain, this latter plant has been traditionally used to deal with inflammatory diseases (Bremner et al., 2009). Because of its high iron, nitrogen, and ascorbic acid contents (Ulukapi et al., 2014), A. stipularis can substitute other Asparagus species for human nutrition. A triterpene saponin (asparagalin A) and two alkaloids (5-hydroxyaspastipuline and aspastipuline) have been purified from the roots of $A$. stipularis (El-Seedi et al., 2012; Galala et al., 2015). Unfortunately, plant extract often present some problems, including long-term instability during storage, as influenced by temperature, light, $\mathrm{pH}$ and oxygen conditions, and low nutrient and phytochemical bioavailability (Coimbra et al., 2011; Fang \& Bhandari, 2010; Woranuch \& Yoksana, 2013). The encapsulation of plant extracts into nanoparticles may reduce the outlined limitations and increase their functional properties (Lu et al., 2016). The polymer PLGA (poly-D, L-lactide-co-glycolide) was widely employed by the food and pharmaceutical industries to protect active ingredients and their controlled release (Stevanovic \& Uskokovic, 2009). PLGA is recognized by the European Medicines Agency (EMA) and the US Food and Drug Administration (FDA), because of its biodegradability and low toxicity (Danhier et al., 2012), and has been previously used to encapsulate plant extracts. Suman and Gupta (2013) encapsulated roots extract of Clerodendrum infortunatum using PLGA to treat hypercholesterolemia, with an encapsulation efficiency of $98.40 \%$. In another study, Ribeiro et al. (2015) developed PLGA nanoparticles loaded with an extract from Uncaria tomentosa, accomplishing significant antiproliferative proprieties against different cancer cell lines, including leukemia, breast cancer, melanoma, lung and colon carcinoma cells.

In the current study, we intended to explore the nutritional composition and bioactive compounds of $A$. stipularis roots and rhizomes and to assess its antioxidant potential and its cytotoxicity in non-tumor cells. In addition, since the extracts derived from $A$. stipularis infusion has not been encapsulated into nanoparticles so far, the encapsulation of the most active extract into PLGA nanoparticles was performed for future food, pharmaceutical, and cosmetic applications.

\section{Materials and methods}

\subsection{Reagents and standards}

Folin-Ciocalteu reagent (2 M), 2,2-Diphenyl-1-picrylhydrazyl (DPPH, free radical, 95\%), phenol, gallic acid (98\%), standards of tocopherols $(\alpha-, \beta-, \gamma$ - and $\delta$-isoforms), organic acids (malic, oxalic and citric acids), fetal bovine serum (FBS), Dulbecco's modified Eagle's medium (DMEM), penicillin, streptomycin, non-essential amino acids, dichloromethane and polyvinyl alcohol (PVA) were bought from Sigma-Aldrich (St. Louis, MO, USA). Chlorotrimethylsilan were obtained from Acros Organics (New Jersey, USA) and hexamethylDisilazane is from MP Biomedicals, Germany. Carbohydrate standards used for identification were purchased from Sigma Chemical Co. (St. Louis, USA). Iron (III) chloride hexahydrate $\left(\mathrm{FeCl}_{3} \cdot 6 \mathrm{H}_{2} \mathrm{O}\right)$ and sodium acetate were obtained from Acros Organics (Geel, Belgium). Metals (Fe, Mn, $\mathrm{Zn}$, and $\mathrm{Cu}$ ) and 2, 2'-Azino-bis-(3-ethylbenzothiazoline-6-sulfonic acid potassium persulfate were purchased from Merck (Darmstadt, Germany). Phenolic compounds standards were purchased from Extrasynthese (Genay, France). PLGA (at ratio lactide to glycolide 50:50) was provided by
Corbion Purac (Amsterdam, The Netherlands). The distilled and bidistilled water was prepared in-house (CBIOS, Lisbon, Portugal).

\subsection{Plant material}

Roots and rhizomes of wild Asparagus stipularis Forssk were harvested in Monastir (Tunisia). Samples were cut into small pieces and dried by active ventilation at $37^{\circ} \mathrm{C}$ for $24-48 \mathrm{~h}$ using an air oven (BOVT270C, Biobase, China). Dried samples were ground in an ultracentrifugal mill ZM 200 (Retsch, Haan, Germany) and put into storage at $-20^{\circ} \mathrm{C}$.

\subsection{Nutritional value of A. stipularis roots and rhizomes}

\subsubsection{Proximate composition}

The standard analytical methods described by the Association of Official Analytical Chemists (AOAC, 2005) were used to determine the moisture, fat, protein, and ash contents. The moisture content was obtained after drying $1 \mathrm{~g}$ of the samples in an air oven $\left(105{ }^{\circ} \mathrm{C}\right)$ (BOV-T270C, Biobase, China). Soxhlet (SER 148 Solvent Extractor, Velp Scientifica, Milan, Italy) and Kjeldahl apparatus (model Pro-Nitro M Kjeldahl Steam Distillation System, Barcelona, Spain) were used to determine the fat and protein content, respectively. The content of ash was analysed by incineration at $550 \pm 10^{\circ} \mathrm{C}$ (Muffle Furnace mLs1200, Thermo Scientific, Monroe, LA, USA). The results were expressed as $\mathrm{g} / 100 \mathrm{~g}$ of fresh weight (fw).

\subsubsection{Available carbohydrates: soluble sugars, oligosaccharides and polyols}

Soluble sugars, oligosaccharides and polyols were extracted following the method previously reported by Mechri et al. (2015). Analysis was performed using a Hewlett-Packard 5890 series II gas chromatograph equipped with an HP-5MS capillary column $(30 \mathrm{~m} \times$ $0.25 \mathrm{~mm}$ ) and a flame ionization detection (FID) system. Individual compounds were identified using the relative retention times in comparison to that of the standards. The internal standard calculation method was adopted to quantify each compound. The analysis was conducted in triplicate, and results were expressed in $\mathrm{mg} / 100 \mathrm{~g}$ fw.

\subsubsection{Dietary fiber (soluble and insoluble)}

The enzymatic-gravimetric methods (AOAC 993.19 and 991.42) were used to determine the fiber content (García-Herrera et al., 2014). Results of total dietary fiber, as well as soluble and insoluble dietary fiber were expressed as $\mathrm{g} / 100 \mathrm{~g}$ fw.

\subsubsection{Energy value}

The energy value was determined using the following equation (European Parliament \& Council of the European Union, 2011):

Energy $(\mathrm{Kcal} / 100 \mathrm{~g}$ fresh weight $)=\left[4 \times\left(\mathrm{g}_{\text {protein }}+\mathrm{g}_{\text {soluble sugar }}\right)+2 \times\left(\mathrm{g}_{\text {fiber }}\right)\right.$ $\left.+9 \times\left(g_{\text {fat }}\right)\right]$

\subsubsection{Mineral elements content}

The mineral elements content was determined following the method 930.05 of AOAC (2005). Copper (Cu), Manganese (Mn), Iron (Fe) and Zinc (Zn), as microelements, were directly quantified by atomic absorption spectroscopy (AAS) (Analyst 200 PerkinElmer equipment (PerkinElmer, Waltham, MA, USA)). For macroelements, Magnesium $(\mathrm{Mg})$, Calcium (Ca), Potassium (K), and Sodium (Na), an additional 1/10 $(\mathrm{mL} / \mathrm{mL})$ dilution of the sample and standards was added to prevent interferences between different elements. The results were expressed in $\mathrm{mg} / 100 \mathrm{~g}$ fw. 


\subsubsection{Fatty acids profile and tocopherols contents}

Fatty acids (FA) were evaluated using the GC method described by Dhibi et al. (2010), with some modifications. FA were analysed using a Hewlett-Packard gas chromatograph (Hewlett-Packard, Palo Alto, CA, USA) provided with a flame ionization detector and a split-splitless injector, set at $270{ }^{\circ} \mathrm{C}$. The identification of FA was performed by comparison of their retention time to pure standards analysed under the same conditions. HP Chemstation integrator was used to calculate the FA peak areas and they were recorded as peak area percentages. Analysis were conducted in triplicate and the results were expressed as relative percentages.

Tocopherols profile was estimated following the procedure adopted by Dias et al. (2013). An HPLC system (Knauer, Smartline system 1000, Berlin, Germany) coupled to a fluorescence detector (FP-2020; Jasco, Easton, MD, USA) programmed for excitation at $290 \mathrm{~nm}$ and emission at $330 \mathrm{~nm}$ was used. Identification of individual tocopherols was performed using the method of chromatographic comparison with authentic standards. Quantification of tocopherols was performed using a calibration curve obtained from the commercial standards of each compound. Analysis was conducted in triplicate and the results were expressed in $\mathrm{mg} / 100 \mathrm{~g}$ fw.

\subsection{Bioactive compounds}

\subsubsection{Organic acids}

A Shimadzu 20 A series UFLC (Shimadzu Corporation, Kyoto, Japan) was used to analyse the organic acids following the method previously described by Barros, Dueñas, Carvalho, Ferreira, and Santos-Buelga (2012). The quantification of organic acids was performed by comparing the area of their peaks to the calibration curves established from the standards of individual organic acid. The experiment was conducted in triplicate and the results were expressed in $\mathrm{g} / 100 \mathrm{~g} \mathrm{fw}$.

\subsubsection{Volatile compounds}

The volatile composition of $A$. stipularis samples was performed following the method of Jelled et al. (2016). Solid Phase Micro-extraction (SPME) was performed followed by Gas-Chromatography coupled to Mass Spectrometry (GC-MS) analysis. The identification of volatile compounds was performed by comparison between their linear retention indices (LRI), library mass spectra as well as MS literature data.

\subsection{Roots and rhizomes infusion extracts preparation and analysis}

The roots and rhizomes infusions were prepared following the procedure previously reported by Dias et al. (2013). Powdered roots or rhizomes $(1 \mathrm{~g})$ were added to $200 \mathrm{~mL}$ of water $\left(100^{\circ} \mathrm{C}\right)$ and left for $5 \mathrm{~min}$ at room temperature. Then, the solutions were filtered, frozen and lyophilized.

\subsubsection{Evaluation of bioactive compounds in the infusions}

2.5.1.1. Organic acids. Dried extracts $(10 \mathrm{mg})$ of roots and rhizomes infusions were re-dissolved in $1 \mathrm{~mL}$ of meta-phosphoric acid (4.5\%), filtered $(0.22 \mu \mathrm{m})$ and analysed as above described. The results were expressed in $\mathrm{mg} / \mathrm{g}$ extract.

2.5.1.2. Total polyphenol (TPC) and total flavonoids (TFC) contents. The Folin-Ciocalteu reagent was used to evaluate the TPC of A. stipularis infusions (Wolfe et al., 2003). The absorbance was measured at $765 \mathrm{~nm}$ against a blank without extract using a UV-vis spectrophotometer (PerkinElmer Lambda 40 UV/VIS Spectrophotometer). The calculation was conducted using a gallic acid calibration curve and results were expressed as $\mathrm{mg}$ of gallic acid equivalents per gram of extract (mg $\mathrm{GAE} / \mathrm{g}$ ).
The colorimetric method adapted by Jia et al. (1999) was adopted to quantify the flavonoids. The absorbance was measured at $510 \mathrm{~nm}$ against the blank without extract. Results were expressed in $\mathrm{mg}$ of catechin equivalents (EC) per gram of extract.

2.5.1.3. HPLC-DAD-ESI/MS analysis for individual phenolic compounds. The analysis of phenolic compounds contained in the extracts was performed by HPLC using double online detection by diode array spectrophotometry and mass spectrometry (MS) (Adouni et al., 2018). A Hewlett-Packard 1100 chromatography (Hewlett-Packard 1100, Agilent Technologies, Santa Clara, CA, USA) equipped with a quaternary pump and a diode array detector (DAD) controlled by a HP ChemStation data-processing station (rev. A.05.04) was used. The identification of individual phenols was performed by comparing their retention characteristics, UV and mass spectra to the available standards, literature data and our database library. The quantitative analysis was conducted using a calibration curve from caffeic acid $(y=529.2 x-7.6)$. The results were expressed in $\mathrm{mg}$ per $100 \mathrm{~g}$ of extract dry weight (dw).

\subsection{In vitro biological activities of A. stipularis infusions extracts}

\subsubsection{Antioxidant activity assays}

2.6.1.1. ABTS radical scavenging activity. An improved ABTS $\bullet+$ method previously described by Re et al. (1999) was adopted. A mixture of 39.2 $\mathrm{mg}$ ABTS and $6.7 \mathrm{mg}$ potassium persulfate was prepared and left in dark at room temperature for $15-16 \mathrm{~h}$ before use. The obtained $\mathrm{ABTS}^{\bullet+}$ solution was diluted with ethanol to obtain the absorbance of $0.700 \pm$ 0.02 at $734 \mathrm{~nm}$. Later, $3.9 \mathrm{~mL}$ of $\mathrm{ABTS}^{\bullet+}$ solution were mixed with each infusion and left to stand for $6 \mathrm{~min}$. The absorbance was measured at $734 \mathrm{~nm}$ in a UV-visible spectrophotometer. Blank was absolute ethanol. The antioxidant activity was determined by calculating the percentage of inhibition of the $\mathrm{ABTS}^{\bullet+}$ radical according to formula (1):

$\%$ Inhibition $=\left(\mathrm{Abs}_{\text {control }}-\mathrm{Abs}_{\text {test }}\right) / \mathrm{Abs}_{\text {control }} \times 100$

$\mathrm{Abs}_{\text {control }}$ is the absorption of the control containing $\mathrm{ABTS}^{\bullet+}(\mathrm{t}=0$ $\mathrm{min})$ and $\mathrm{Abs}_{\text {test }}$ is the absorption of the tested infusion $(t=6 \mathrm{~min})$. The concentration of the extract that provides $50 \%$ of antioxidant activity (EC50) was calculated. Trolox was used as standard and analyses were carried out in triplicate.

2.6.1.2. DPPH radical scavenging activity. The Brand-Williams et al. (1995) method was used with some modifications. A $50 \mu \mathrm{L}$ aliquot of sample was mixed with $2 \mathrm{~mL}$ of DPPH. methanolic solution $(89.7 \mu \mathrm{M})$. The mixture was left in the dark at room temperature for $45 \mathrm{~min}$ and the absorption measured at $517 \mathrm{~nm}$. The experiment was carried out in triplicate. The antioxidant activity was determined by formula (2):

$\%$ Inhibition $=\left(\mathrm{Abs}_{\text {control }}-\mathrm{Abs}_{\text {test }}\right) / \mathrm{Abs}_{\text {control }} \times 100$

$\mathrm{Abs}_{\text {control }}$ is the absorption of the control containing DPPH ${ }^{\bullet}$ and $\mathrm{Abs}_{\text {test }}$ is the absorption of the tested infusion. The EC50 was calculated. Trolox was used as a standard.

2.6.1.3. Ferric reducing antioxidant power (FRAP). The Benzie and Strain (1996) method was used with some modifications. Each infusion $(50 \mu \mathrm{L})$ was mixed with distilled water $(150 \mu \mathrm{L})$ and FRAP reagent $(1500 \mu \mathrm{L})$. The mixture was vortexed for $15 \mathrm{~s}$ and left in the dark $(2 \mathrm{~h}$, $37{ }^{\circ} \mathrm{C}$ ). The absorbance was measured at $690 \mathrm{~nm}$ with a UV-vis spectrophotometer (PerkinElmer Lambda 40 UV/VIS Spectrophotometer). The concentration of the extract that gives 0.5 absorbance $\left(\mathrm{EC}_{50}\right)$ was calculated from the graph against the concentration of infusions. The analysis was carried out in triplicate. Trolox was used as a standard.

\subsubsection{Cytotoxic activity}

A porcine liver primary cell culture (PLP2) was used to perform a 
preliminary study of in vitro toxicity of $A$. stipularis infusion following the methodology previously described (Guimarães et al., 2013). The results were expressed in $\mathrm{GI}_{50}$ values, the concentration that inhibited $50 \%$ of the net cell growth. As positive control, ellipticine was used.

\subsection{Extract encapsulation into nanoparticles}

\subsubsection{PLGA nanoparticles production}

A modified solvent emulsification-evaporation method previously described by Fonte et al. (2014) was adopted to produce PLGA nanoparticles (NPs). Briefly, an organic phase was prepared by dissolving PLGA 50:50 (100 mg) in dichloromethane $(2 \mathrm{~mL})$. After that, $0.2 \mathrm{~mL}$ of roots infusion (IR) were added to the previous solution and sonicated for $30 \mathrm{~s}$ at $70 \%$ of amplitude using a Q125 Sonicator (QSonica Sonicators, Newtown, CT, USA). Later, the emulsion was rapidly poured into PVA $(10 \mathrm{~mL}, 2 \%)$ and sonicated using the same conditions. Next, the emulsion was magnetically stirred for $3 \mathrm{~h}$ at room temperature to evaporate the organic solvent. Control unloaded PLGA NPs were produced following the same procedure.

\subsubsection{Physicochemical properties of nanoparticles}

A Coulter Nano-sizer Delsa ${ }^{\mathrm{TM}}$ Nano C from Beckman Coulter, Inc. (Brea, CA, USA) was used to determine the particle size, polydispersity index (PDI) and zeta potential (ZP) of the Asparagus loaded NPs. The samples were diluted with distilled water. The mean particle size and PDI of NPs were analysed by dynamic light scattering (DLS). The zeta potential was determined by electrophoretic mobility analysis. Experiments were performed in triplicate.

\subsubsection{Determination of encapsulation efficiency (EE)}

Total phenolic content analysis (TPC) using the Folin-Ciocalteu assay, as above described (section 2.5.1.2) permitted to determine the encapsulation efficiency (EE) of roots infusion in the PLGA NPs. The amount of TPC entrapped within the nanoparticles was evaluated by measuring the amount of unloaded free total phenolic content in the supernatant recovered after ultracentrifugation of the nanoparticle suspension at 15,000 rpm for $20 \mathrm{~min}$. After centrifugation, the nanoparticles were re-suspended in bidistilled water, followed by freezedrying ( $48 \mathrm{~h},-50{ }^{\circ} \mathrm{C}, 400 \mathrm{mTorr}$ ) using a LABCONCO FreeZone $25{ }^{\circledR}$ freeze dryer (Kansas City, MO, USA). The TPC was determined by ultraviolet-visible (UV-VIS) spectrophotometry at $765 \mathrm{~nm}$.

EE was calculated according to formula (3): range of $600-4000 \mathrm{~cm}^{-1}$ with 50 scans at a resolution of $4 \mathrm{~cm}^{-1}$.

\subsubsection{Differential scanning calorimetry (DSC)}

The roots infusion, PLGA, physical mixture (roots infusion and PLGA) and unloaded and loaded NPs were analysed using a differential Scanning Calorimeter DSC 200 F3 Maia (Netzsch, Selb, Germany). Each sample $(2 \mathrm{mg}$ ) was sealed in an aluminium pan. The heating curves were recorded using a heating rate of $10^{\circ} \mathrm{C} / \mathrm{min}$ from $20^{\circ} \mathrm{C}$ to $260{ }^{\circ} \mathrm{C}$. An empty pan was used as reference.

\subsection{Statistical analysis}

All the extractions and analyses were carried out in triplicate. Results are expressed as mean values \pm standard deviation (SD), being analysed using a Student's t-test, with $p=0.05$. The analysis was performed using Origin Pro 8 (Origin Lab).

\section{Results and discussion}

\subsection{Nutritional value and bioactive compounds of A. stipularis roots and rhizomes}

The results of the nutritional characterization of $A$. stipularis roots and rhizomes are presented in Table 1 . They showed a similar proximate composition: moisture was the major component, followed by carbohydrates, protein, fat and ash. In our previous study on shoots of A. stipularis (Adouni et al., 2018), a higher moisture content was found (82.38\%), with consequent lower percentages of the other fractions $(0.82,1.19$ and $3.64 \mathrm{~g}$ per $100 \mathrm{~g}$ for ash, proteins and fat, respectively).

The major differences between the two samples were observed for dietary fiber and mineral contents. Indeed, the contents of total soluble $(2.22 \pm 0.14 \mathrm{~g} / 100 \mathrm{~g} \mathrm{fw})$ and insoluble dietary fiber $(30.88 \pm 3.21 \mathrm{~g} /$ $100 \mathrm{~g} \mathrm{fw}$ ) in the roots were two-fold higher than those in the rhizomes $(1.40 \pm 0.11$ and $14.06 \pm 1.71 \mathrm{~g} / 100 \mathrm{~g}$ fw, respectively). In rhizomes, a difference around 19\% existed between the amount of total carbohydrates and the sum of fiber and soluble sugars, suggesting that a part of carbohydrates was not included under those fractions, which should be explained by the presence of non-fiber oligo- or carbohydrates, such as starch. Dietary fiber has received much importance based on its numerous health benefits for instance in glycemic control in diabetes (Weickert et al., 2018), decreasing cholesterol levels and inflammation (Wannamethee et al., 2009; Muller et al., 2018). The current fiber intake prescribed by the Food and Nutrition Board ranges between 21 and 38

$E E \%=\frac{\text { Amount of TPC in the encapsulated extract }- \text { Amount of TPC in the supernatant }}{\text { Amount of TPC in the encapsulated extract }} \times 100$

\subsubsection{Scanning electron microscopy (SEM)}

The morphology of NPs was analysed by SEM using a FEI Quanta 400 FEG SEM (FEI, Hillsboro, OR, USA). Briefly, the freeze-dried NPs were placed on metal stubs. Then, the NPs were vacuum-coated with a layer of Gold/Palladium for $60 \mathrm{~s}$ with a current of $15 \mathrm{~mA}$.

\subsubsection{Fourier transform infrared spectroscopy (FTIR)}

The molecular characterization of roots infusion, PLGA, physical mixture (roots infusion and PLGA) and unloaded and loaded NPs was performed by FTIR. The analysis was conducted with a MB3000 FTIR spectrometer (ABB, Zurich, Switzerland) linked to a MIRacle single reflection attenuated total reflectance (ATR) accessory from PIKE Technologies (Madison, WI, USA). All spectra were registered in the g/day for adults, depending on life stage groups (Trumbo et al., 2002). Thus, a portion of $100 \mathrm{~g}$ of rhizomes or roots of A. stipularis could cover at least 74 and $87 \%$ of this dietary recommendation, respectively. The recommended European consumption of fiber is estimated to be 20 $\mathrm{g} /$ person/day, so an increase in fiber consumption seems needed, a goal to which supplements of the studied samples could contribute.

The contents of essential minerals $\mathrm{Na}, \mathrm{Ca}, \mathrm{K}, \mathrm{Mg}$ and trace minerals $\mathrm{Zn}, \mathrm{Fe}, \mathrm{Mn}$ and $\mathrm{Cu}$ of the Asparagus samples are also shown in Table 1. Among trace minerals, Fe was the main element in both samples. Iron is involved in many aspects of energy metabolism and is an important component in the structure and function of haemoglobin, myoglobin and cytochromes and a co-factor for many enzymes (Puntarulo, 2005). Recommended values for daily Fe intake are about $16-20 \mathrm{mg}$ /day for women under $50-55$ years old and $8-10 \mathrm{mg} /$ day for men and elderly women (EFSA, 2006). Thus, a portion of $100 \mathrm{~g}$ of roots could cover at 
Table 1

Proximate composition, mineral elements and energy value of Asparagus stipularis roots and rhizomes.

\begin{tabular}{lll}
\hline Proximate composition $(\mathrm{g} / 100 \mathrm{~g} \mathrm{fw})$ & Roots & Rhizomes \\
\hline Moisture & $57.4 \pm 0.8^{\mathrm{a}}$ & $59 \pm 1^{\mathrm{a}}$ \\
Crude proteins & $6.3 \pm 0.2^{\mathrm{b}}$ & $4.9 \pm 0.2^{\mathrm{a}}$ \\
Total Fat & $0.27 \pm 0.04^{\mathrm{b}}$ & $0.15 \pm 0.03^{\mathrm{a}}$ \\
Total ash & $1.99 \pm 0.03^{\mathrm{b}}$ & $1.44 \pm 0.07^{\mathrm{a}}$ \\
Total carbohydrates & $91.47 \pm 0.15^{\mathrm{b}}$ & $93.45 \pm 0.27^{\mathrm{a}}$ \\
Soluble sugars & $1.13 \pm 0.01^{\mathrm{b}}$ & $0.67 \pm 0.01^{\mathrm{a}}$ \\
Total dietary fiber & $33 \pm 3^{\mathrm{b}}$ & $15 \pm 1^{\mathrm{a}}$ \\
\hline Soluble dietary fiber & $2.22 \pm 0.14^{\mathrm{b}}$ & $1.40 \pm 0.11^{\mathrm{a}}$ \\
Insoluble dietary fiber & $30.88 \pm 3.21^{\mathrm{b}}$ & $14.06 \pm 1.71^{\mathrm{a}}$ \\
\hline Macro and microelements (mg/100 g fw) & & \\
\hline Fe & $15.5 \pm 0.2^{\mathrm{b}}$ & $8.5 \pm 0.3^{\mathrm{a}}$ \\
Cu & $0.98 \pm 0.01^{\mathrm{b}}$ & $0.63 \pm 0.03^{\mathrm{a}}$ \\
Mn & $0.28 \pm 0.01^{\mathrm{b}}$ & $0.13 \pm 0.05^{\mathrm{a}}$ \\
$\mathrm{Zn}$ & $0.93 \pm 0.03^{\mathrm{a}}$ & $1.7 \pm 0.02^{\mathrm{b}}$ \\
\hline Ca & $332 \pm 6^{\mathrm{b}}$ & $211 \pm 2^{\mathrm{a}}$ \\
$\mathrm{Mg}$ & $106 \pm 4^{\mathrm{a}}$ & $128.0 \pm 0.3^{\mathrm{b}}$ \\
$\mathrm{Na}$ & $12.0 \pm 0.3^{\mathrm{a}}$ & $14.3 \pm 0.3^{\mathrm{b}}$ \\
$\mathrm{K}$ & $161 \pm 4^{\mathrm{a}}$ & $278 \pm 5^{\mathrm{b}}$ \\
Energy (kcal/100 g fw) & $98 \pm 6^{\mathrm{b}}$ & $55 \pm 4^{\mathrm{a}}$ \\
\hline
\end{tabular}

In each row different letters mean significant differences $(\mathrm{p}<0.05)$.

least $77 \%$ of Recommended Dietary Allowance (RDA) for women and more than $100 \%$ of RDA for men. Considering the analysed essential minerals (Table 1$)$, the rhizomes revealed higher contents of $\mathrm{Na}(14.3 \pm$ $0.3 \mathrm{mg} / 100 \mathrm{~g} \mathrm{fw})$ and $\mathrm{K}(278 \pm 5 \mathrm{mg} / 100 \mathrm{~g} \mathrm{fw})$ than roots (12 and 161 $\mathrm{mg} / 100 \mathrm{~g}$ fw, respectively). $\mathrm{K}$ and $\mathrm{Na}$ control the ionic balance of the human body and sustain tissue excitability. $\mathrm{Na} / \mathrm{K}$ ratios lower than 1 , as existing in (most) vegetables contribute to ameliorate sodium-related health disorders and in particular hypertension. This ratio was maintained well below 1 in the studied samples as well as in the shoots of A. stipularis reported in our previous work (Adouni et al., 2018). Magnesium is a necessary mineral for the human body. It is required as a co-factor in many enzymes and it plays a role in nucleic acid synthesis. Intakes of $350 \mathrm{mg} /$ day and $300 \mathrm{mg} /$ day have been recommended by the EFSA for men and women, respectively (EFSA, 2015). A higher content of $\mathrm{Mg}$ was found for the rhizomes than for roots. Calcium was the essential mineral present in higher levels in A. stipularis roots, a notable concentration taking into account that the needs of this elements are situated around $1 \mathrm{~g} /$ day for adults and, but for dairy products, there is a scarcity of dietary sources. This element possesses great nutritional

Table 2

Soluble sugars and organic acids composition in Asparagus stipularis roots and rhizomes.

\begin{tabular}{|c|c|c|}
\hline Soluble sugars $(\mathrm{mg} / 100 \mathrm{~g} \mathrm{fw})$ & Roots & Rhizomes \\
\hline Fructose & $26.5 \pm 0.3^{\mathrm{a}}$ & $81.4 \pm 0.9^{b}$ \\
\hline Glucose & $150 \pm 2^{\mathrm{b}}$ & $45.6 \pm 0.3^{\mathrm{a}}$ \\
\hline Sucrose & $286 \pm 4^{\mathrm{a}}$ & $466 \pm 5^{\mathrm{b}}$ \\
\hline Galactose & $56 \pm 1^{\mathrm{b}}$ & $13.4 \pm 0.3^{\mathrm{a}}$ \\
\hline Rhamnose & $112 \pm 3^{\mathrm{b}}$ & $5.32 \pm 0.03^{\mathrm{a}}$ \\
\hline Xylose & $39 \pm 1^{\mathrm{b}}$ & $2.59 \pm 0.07^{\mathrm{a}}$ \\
\hline Arabinose & nd & $3.5 \pm 0.1$ \\
\hline Raffinose & $124 \pm 4^{\mathrm{b}}$ & $19.5 \pm 0.3^{\mathrm{a}}$ \\
\hline Trehalose & nd & $20.4 \pm 0.3$ \\
\hline Sorbitol & $34.0 \pm 0.6^{\mathrm{b}}$ & $5.5 \pm 0.3^{\mathrm{a}}$ \\
\hline Inositol & $304 \pm 3^{b}$ & $9.40 \pm 0.06^{\mathrm{a}}$ \\
\hline \multicolumn{3}{|l|}{ Organic acids ( $g / 100 \mathrm{~g} f w)$} \\
\hline Oxalic acid & $0.25 \pm 0.03^{\mathrm{b}}$ & $0.12 \pm 0.03^{\mathrm{a}}$ \\
\hline Malic acid & $\operatorname{tr}$ & $\operatorname{tr}$ \\
\hline Citric acid & $0.07 \pm 0.01^{\mathrm{a}}$ & $0.15 \pm 0.04^{\mathrm{b}}$ \\
\hline Total organic acids & $0.33 \pm 0.04^{b}$ & $0.27 \pm 0.01^{\mathrm{a}}$ \\
\hline
\end{tabular}

In each row different letters mean significant differences $(\mathrm{p}<0.05)$; nd: not detected; tr: traces. interest because it is necessary for metabolic reactions, bone formation, teeth, muscle and heart function and also can act as activators for enzyme systems (FAO/WHO, 2001, pp. 223-224). Despite the differences found between roots and rhizomes in the concentrations of microelements and macroelements in the current study, in general, the Asparagus samples can be considered adequate sources of essential mineral elements that could be consumed within the current diet.

The content in total soluble sugars of $A$. stipularis roots $(1.13 \mathrm{~g} / 100 \mathrm{~g}$ $\mathrm{fw})$ was higher than in rhizomes $(0.67 \mathrm{~g} / 100 \mathrm{~g} \mathrm{fw})$ (Table 2). Arabinose and trehalose were detected only in rhizomes, which also presented higher contents in fructose and especially sucrose- while the remaining sugars are found in greater concentrations in roots, namely glucose, galactose, rhamnose, xylose, raffinose, sorbitol and inositol.

The organic acid profiles are summarized in Table 2. Oxalic and citric acid were quantified, while malic acid was detected in trace amounts in both samples. Those organic acids were also detected in spears of A. stipularis, reported in our previous work (Adouni et al., 2018). The roots showed two-fold higher concentration of oxalic acid than the rhizomes, while the opposite happened with citric acid. Actually, rhizomes of $A$. stipularis revealed a citric acid content higher than other previously analysed wild edible plants, such as bulbs and pseudo stems of Allium ampeloprasum (Sánchez-Mata et al., 2012), fruits of Arbutus unedo (Pereira et al., 2013) or leaves of Anchusa azurea (Morales et al.,

Table 3

Distribution of main fatty acid composition (relative percentage on total fatty acids) and tocopherols (mg/100 g fw) in Asparagus stipularis roots and rhizomes.

\begin{tabular}{|c|c|c|}
\hline \multirow{2}{*}{$\frac{\text { Fatty acids }}{\text { Saturated }}$} & \multicolumn{2}{|c|}{ Relative percentage (\%) } \\
\hline & Roots & Rhizomes \\
\hline $\mathrm{C} 6: 0$ & $0.37 \pm 0.01^{\mathrm{a}}$ & $0.36 \pm 0.02^{\mathrm{a}}$ \\
\hline $\mathrm{C} 12: 0$ & $2.14 \pm 0.05^{\mathrm{a}}$ & $2.27 \pm 0.03^{\mathrm{b}}$ \\
\hline $\mathrm{C} 14: 0$ & $0.14 \pm 0.04^{\mathrm{a}}$ & $0.13 \pm 0.01^{\mathrm{a}}$ \\
\hline $\mathrm{C} 15: 0$ & $0.81 \pm 0.04^{\mathrm{b}}$ & $0.51 \pm 0.03^{\mathrm{a}}$ \\
\hline $\mathrm{C} 16: 0$ & $22.82 \pm 0.1^{\mathrm{a}}$ & $24.10 \pm 0.07^{b}$ \\
\hline $\mathrm{C} 17: 0$ & $1.4 \pm 0.2^{\mathrm{b}}$ & $1.03 \pm 0.04^{\mathrm{a}}$ \\
\hline C18:0 & $8.21 \pm 0.05^{\mathrm{a}}$ & $8.57 \pm 0.06^{\mathrm{b}}$ \\
\hline $\mathrm{C} 20: 0$ & $3.7 \pm 0.2^{\mathrm{a}}$ & $3.99 \pm 0.05^{\mathrm{b}}$ \\
\hline $\mathrm{C} 22: 0$ & $0.57 \pm 0.1^{\mathrm{a}}$ & $0.70 \pm 0.01^{\mathrm{b}}$ \\
\hline $\mathrm{C} 23: 0$ & $0.79 \pm 0.02^{\mathrm{a}}$ & $0.80 \pm 0.05^{\mathrm{a}}$ \\
\hline $\mathrm{C} 24: 0$ & $0.16 \pm 0.01^{\mathrm{a}}$ & $0.15 \pm 0.02^{\mathrm{a}}$ \\
\hline \multicolumn{3}{|l|}{ Monounsaturated } \\
\hline C16:1 (n-9) & $6.4 \pm 0.1^{b}$ & $2.24 \pm 0.05^{\mathrm{a}}$ \\
\hline C18:1 (n-9) & $19.3 \pm 0.2^{\mathrm{a}}$ & $20.3 \pm 0.1^{\mathrm{b}}$ \\
\hline C20:1 (n-9) & $0.68 \pm 0.05^{\mathrm{a}}$ & $0.74 \pm 0.07^{\mathrm{b}}$ \\
\hline \multicolumn{3}{|l|}{ Polyunsaturated } \\
\hline C18:2 (n-6) & $26.6 \pm 0.2^{\mathrm{a}}$ & $28.0 \pm 0.1^{\mathrm{b}}$ \\
\hline $\mathrm{C} 18: 3$ (n-3) & $5.3 \pm 0.2^{\mathrm{a}}$ & $5.5 \pm 0.1^{\mathrm{a}}$ \\
\hline $\mathrm{C} 20: 2(\mathrm{n}-6)$ & $0.8 \pm 0.1^{\mathrm{a}}$ & $0.8 \pm 0.1^{\mathrm{b}}$ \\
\hline Total SFA & $41.1 \pm 0.4^{\mathrm{a}}$ & $42.6 \pm 0.3^{\mathrm{b}}$ \\
\hline Total MUFA & $26.3 \pm 0.4^{b}$ & $23.3 \pm 0.3^{\mathrm{a}}$ \\
\hline Total PUFA & $32.7 \pm 0.4^{\mathrm{a}}$ & $34.4 \pm 0.3^{\mathrm{b}}$ \\
\hline PUFA/SFA & $0.79 \pm 0.02^{\mathrm{a}}$ & $0.81 \pm 0.01^{\mathrm{b}}$ \\
\hline \multicolumn{3}{|c|}{ 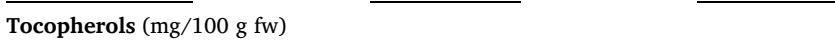 } \\
\hline$\alpha$-Tocopherol & $0.060 \pm 0.001^{\mathrm{a}}$ & $0.05 \pm 0.01^{\mathrm{a}}$ \\
\hline$\gamma$-Tocopherol & $0.030 \pm 0.002^{\mathrm{a}}$ & $0.03 \pm 0.01^{\mathrm{a}}$ \\
\hline$\delta$ - Tocopherol & $0.010 \pm 0.001$ & nd \\
\hline$\overline{\text { Total tocopherols }}$ & $0.10 \pm 0.01^{\mathrm{a}}$ & $\overline{0.07 \pm 0.001^{\mathrm{a}}}$ \\
\hline
\end{tabular}

In each row different letters mean significant differences $(\mathrm{p}<0.05)$. C6:0 Pentanoic acid, C12:0 Lauric acid, C14:0 myristic acid, C15:0 pentadecanoic acid, C16:0 palmitic acid, C16:1 palmitoleic acid, C17:0 heptadecanoic acid, C18:0 stearic acid, C18:1n9c oleic acid, C18:2n6c linoleic acid, C18:3n6 $\gamma$-linolenic acid, C18:3n $3 \alpha$-linolenic acid, C20:0 arachidic acid, C20:1 eicosenoic acid, C20:2 eicosadienoic acid, C22:0 behenic acid, C23:0 tricosylic acid, C24:0 lignoceric acid. SFA: saturated fatty acids; MUFA: monounsaturated fatty acids; PUFA: polyunsaturated fatty acids. 
2014). To the best of our knowledge, the present study is the first report on the organic acid composition of $A$. stipularis roots and rhizomes, so there are no data to compare them with the present results. However, previous studies reported the organic acid composition of other Asparagus species (Jime'nez-Sánchez et al., 2016; Slatnar et al., 2018). Zhang et al. (2020) conducted a study on both green and white Asparagus. Results showed the presence of several organic acids such as fumaric, ascorbic, malic and citric acids.

The oxalic acid/Ca ratio was 0.752 and 0.568 for roots and rhizomes, respectively, which is much lower than 2.5 , which suggests that the consumption of $A$. stipularis samples doesn't reduce the bioavailability of dietary Ca by the formation of insoluble calcium oxalate (Adouni et al., 2018).

The fatty acid profiles of the roots and rhizomes of $A$. stipularis were determined (Table 3). Saturated fatty acids (SFA) predominated over monounsaturated fatty acids (MUFA) and polyunsaturated fatty acids (PUFA) in both samples, though presenting the highest percentage in rhizomes (42.6 $\pm 0.3 \%)$. Among them, palmitic acid (C16:0) presented the main contribution $(24.10 \pm 0.07 \%)$. The roots showed higher levels of MUFA $(26.3 \pm 0.4 \%)$ than rhizomes $(23.3 \pm 0.3 \%)$, with prevalence of oleic acid (C18:1) in both samples. On the other hand, PUFA were higher in rhizomes $(34.4 \pm 0.3 \%)$, mainly due to linoleic acid $(28.0 \pm$ $0.1 \%)$. The ratio of PUFA/SFA was higher than 0.45 in both samples, which is considered an adequate nutritional relation for food products (Simopoulos, 1997). Very small contents of tocopherols were determined in roots and rhizomes of $A$. stipularis, with $\alpha$ and $\gamma$ isoforms present in both samples, and $\delta$-tocopherol present only in the roots (Table 3).

Besides their sensory properties, volatile aroma compounds present in plant foods demonstrated important biological functions for human health as well as for plant and food protection (Hubert et al., 2008; Boulogne et al., 2012; Keiler et al., 2013). Thus, volatile aroma can be considered as potentially safe alternatives to chemical flavoring in foods and functional products. Alcohols, esters, aldehydes, hydrocarbons, terpenoids, apocarotenes and other compounds were identified in the volatile profile of $A$. stipularis roots and rhizomes, being aldehydes and hydrocarbons the main chemical classes (Table 4). Limonene and nonanal were the major volatile compounds detected, presenting the highest level in roots (20.8 $\pm 0.1 \%$ and $12.6 \pm 0.1 \%$, respectively). Limonene is added as a flavoring compound in perfumes, soaps, and foods (Whysner \& Williams, 1996), while nonanal has been used for the improvement of oral breath odor and the diagnosis of some human diseases (Itoh et al., 2013).

\subsection{Bioactive compounds in A. stipularis infusions}

\subsubsection{Organic acids}

The organic acid profile of $A$. stipularis infusions is given in Table 5. Oxalic and citric acids were the major acids detected in the preparation of the roots, being oxalic acid the most abundant one $(17.60 \pm 0.05 \mathrm{mg} /$ $\mathrm{g}$ extract). Only citric acid was present in the rhizome infusion, and its content was lower than the one determined in that of the roots. Recent studies have shown that organic acids exert some health benefits such as antioxidant (Liu et al., 2019) and antimicrobial activities (Mani-Lopez et al., 2012).

\subsubsection{Phenolic compounds}

Asparagus can be considered as products of interest due to their contents in phytochemicals, such as phenolic compounds (Fuentes-Alventosa et al., 2013). As a first approach, total phenolic (TPC) and flavonoids contents (TFC) of roots and rhizomes infusions were estimated by spectrophotometric methods (Table 5 ). The roots extract was richer in phenolic compounds than rhizomes, where no flavonoids were detected in the TFC assay. Similarly, Hamdi et al. (2016) detected flavonoids in ethanol extracts of leaves and pericarps of $A$. albus, but not in those of rhizomes. It must be said, however, that it was not possible to
Table 4

Volatile compounds characterized in Asparagus stipularis roots and rhizomes.

\begin{tabular}{|c|c|c|c|}
\hline \multirow[t]{2}{*}{ Compound } & \multirow[t]{2}{*}{ 1.r.i.* } & \multicolumn{2}{|l|}{ Content (\%) } \\
\hline & & Roots & Rhizomes \\
\hline Hexanal & 802 & $1.3 \pm 0.1^{\mathrm{a}}$ & $8.5 \pm 0.1^{\mathrm{b}}$ \\
\hline 1-Hexanol & 869 & nd & $0.9 \pm 0.1$ \\
\hline Heptanal & 901 & nd & $1.2 \pm 0.1$ \\
\hline Benzaldehyde & 962 & $1.7 \pm 0.1$ & nd \\
\hline Hexanoic acid & 987 & $7.3 \pm 0.2^{\mathrm{a}}$ & $10.2 \pm 0.1^{\mathrm{b}}$ \\
\hline Octanal & 1002 & $1.6 \pm 0.1^{\mathrm{b}}$ & $1.1 \pm 0.1^{\mathrm{a}}$ \\
\hline$p$-Cymene & 1028 & nd & $1.0 \pm 0.1$ \\
\hline Limonene & 1032 & $20.8 \pm 0.1^{\mathrm{b}}$ & $18.8 \pm 0.2^{\mathrm{a}}$ \\
\hline$\gamma$-Terpinene & 1063 & $2.5 \pm 0.1^{\mathrm{a}}$ & $2.9 \pm 0.1^{\mathrm{b}}$ \\
\hline 3-Octen-2-one & 1043 & nd & $2.9 \pm 0.1$ \\
\hline Nonanal & 1104 & $12.6 \pm 0.1^{\mathrm{b}}$ & $12.2 \pm 0.1^{\mathrm{a}}$ \\
\hline (E,Z)-3,5-Octadien-2-one & 1072 & nd & $2.6 \pm 0.3$ \\
\hline (E)-2-Undecene & 1106 & $4.8 \pm 0.1^{\mathrm{b}}$ & $2.9 \pm 0.2^{\mathrm{a}}$ \\
\hline Pentylisovalerate & 1108 & $1.7 \pm 0.1$ & nd \\
\hline (Z)-3-Hexenyl isobutyrate & 1143 & $2.3 \pm 0.1^{\mathrm{b}}$ & $1.7 \pm 0.2^{\mathrm{a}}$ \\
\hline 2-Ethylhexyl acetate & 1155 & $9.9 \pm 0.1^{\mathrm{b}}$ & $3.8 \pm 0.3^{\mathrm{a}}$ \\
\hline trans-Linalool oxide (furanoid) & 1090 & nd & $1.4 \pm 0.2$ \\
\hline (E,E)-3,5-octadien-2-one & 1093 & nd & $1.2 \pm 0.1$ \\
\hline$\alpha$-Terpineol & 1191 & $1.8 \pm 0.1$ & nd \\
\hline Linalool & 1101 & nd & $1.3 \pm 0.2$ \\
\hline Safranal & 1197 & $3.4 \pm 0.3$ & nd \\
\hline Decanal & 1206 & $5.7 \pm 0.1^{\mathrm{b}}$ & $5.3 \pm 0.2^{\mathrm{a}}$ \\
\hline$n$-Tridecane & 1300 & $1.9 \pm 0.1$ & nd \\
\hline (E)-2-Nonenal & 1163 & nd & $0.9 \pm 0.1$ \\
\hline$n$-Undecane & 1100 & nd & $1.2 \pm 0.1$ \\
\hline$n$-Dodecane & 1200 & nd & $1.00 \pm 0.07$ \\
\hline$n$-Tridecane & 1300 & nd & $1.0 \pm 0.1$ \\
\hline$\alpha$-Terpinyl acetate & 1352 & $1.3 \pm 0.2^{\mathrm{a}}$ & $1.6 \pm 0.2^{\mathrm{b}}$ \\
\hline 2-Methylbutyl heptanoate & 1355 & $2.1 \pm 0.2$ & nd \\
\hline 2-Methylundecanal & 1368 & $1.3 \pm 0.1$ & nd \\
\hline$\alpha$-Copaene & 1377 & $3.6 \pm 0.1^{\mathrm{b}}$ & $2.1 \pm 0.1^{\mathrm{a}}$ \\
\hline$n$-Tetradecane & 1400 & $3.2 \pm 0.1^{\mathrm{b}}$ & $1.1 \pm 0.1^{\mathrm{a}}$ \\
\hline$\beta$-Caryophyllene & 1419 & $2.2 \pm 0.2$ & nd \\
\hline$\beta$-Bisabolene & 1508 & nd & $3.4 \pm 0.2$ \\
\hline trans- $\alpha$-Bergamotene & 1437 & nd & $2.7 \pm 0.2$ \\
\hline (E)-Geranylacetone & 1455 & $2.2 \pm 0.1^{\mathrm{b}}$ & $1.9 \pm 0.1^{\mathrm{a}}$ \\
\hline$n$-Pentadecane & 1500 & $2.4 \pm 0.1$ & nd \\
\hline Monoterpene hydrocarbons & - & $23.6 \pm 0.4^{\mathrm{b}}$ & $22.6 \pm 0.3^{\mathrm{a}}$ \\
\hline Oxygenated monoterpenes & - & $3.2 \pm 0.1^{\mathrm{a}}$ & $4.3 \pm 0.2^{\mathrm{b}}$ \\
\hline Sesquiterpene hydrocarbons & - & $5.7 \pm 0.1^{\mathrm{a}}$ & $8.2 \pm 0.2^{\mathrm{b}}$ \\
\hline Apocarotenes & - & $5.6 \pm 0.3^{\mathrm{b}}$ & $1.70 \pm 0.07^{\mathrm{a}}$ \\
\hline Non-terpene derivatives & - & $58.8 \pm 0.2^{\mathrm{a}}$ & $58.4 \pm 0.2^{\mathrm{a}}$ \\
\hline Total identified & & 97.80 & 95.80 \\
\hline
\end{tabular}

*1.r.i.: linear retention index; In each row different letters mean significant differences $(\mathrm{p}<0.05)$; nd: not detected.

Table 5

Organic acids and phenolic fractions in infusion extracts of Asparagus stipularis roots and rhizomes.

\begin{tabular}{|c|c|c|}
\hline & Roots infusion & Rhizomes infusion \\
\hline \multicolumn{3}{|l|}{ Organic acids (mg/g extract) } \\
\hline Oxalic acid & $17.60 \pm 0.05$ & $\operatorname{tr}$ \\
\hline Malic acid & $\operatorname{tr}$ & $\operatorname{tr}$ \\
\hline Citric acid & $7.6 \pm 0.3^{b}$ & $1.31 \pm 0.03^{\mathrm{a}}$ \\
\hline Total organic acids & $25.2 \pm 0.2^{\mathrm{b}}$ & $1.31 \pm 0.03^{\mathrm{a}}$ \\
\hline Total polyphenols (mg GAE/g extract) & $58.40 \pm 2.10^{\mathrm{b}}$ & $22.0 \pm 0.70^{\mathrm{a}}$ \\
\hline Total flavonoids (mg CE/g extract) & $20.90 \pm 0.30$ & nd \\
\hline
\end{tabular}

In each row different letters mean significant differences $(\mathrm{p}<0.05)$; $\operatorname{tr}$ : traces; nd: not detected.

find additional flavonoids in the HPLC analysis of single phenolic rhizomes or roots.

According to Petropoulos et al. (2017), the phenolic profiles varies depending on plant part, genotype, and growing and processing conditions, leading to large variations in both content and composition. Phenolic compounds are plant secondary metabolites involved in the 
Table 6

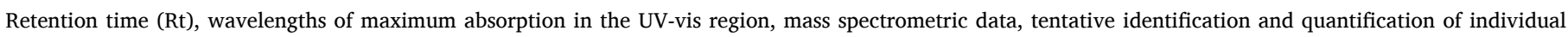
phenolic compounds in Asparagus stipularis rhizomes and roots infusions (mg per $100 \mathrm{~g}$ of $\mathrm{dw}$ ).

\begin{tabular}{|c|c|c|c|c|c|c|c|}
\hline \multirow[t]{2}{*}{ Peak } & \multirow[t]{2}{*}{ Rt (min) } & \multirow[t]{2}{*}{$\lambda_{\max }(\mathrm{nm})$} & \multirow[t]{2}{*}{ Pseudomolecular ion $[\mathrm{M}-\mathrm{H}]^{-}(\mathrm{m} / \mathrm{z})$} & \multirow[t]{2}{*}{$\operatorname{MS}^{2}(m / z)$} & \multirow[t]{2}{*}{ Tentative identification } & \multicolumn{2}{|c|}{ Quantification (mg/100 g dw) } \\
\hline & & & & & & Rhizomes & Roots \\
\hline 1 & 9 & 294,323 & 179 & 135 & Caffeic acid & $0.16 \pm 0.03^{\mathrm{a}}$ & $19.83 \pm 0.1^{\mathrm{b}}$ \\
\hline 2 & 10.2 & - & 353 & 179,135 & Caffeolquinic acid & nd & $3.25 \pm 0.02$ \\
\hline 3 & 15 & 323 & 267 & $252,193,175,160,133$ & Feruloyl glycerol & $1.69 \pm 0.13^{\mathrm{a}}$ & $5.02 \pm 0.3^{\mathrm{b}}$ \\
\hline 4 & 29.2 & 315 & 413 & $134,160,193,145,119$ & Coumaroylferuloyl glycerol I & $1.11 \pm 0.02^{\mathrm{a}}$ & $12.48 \pm 0.03^{\mathrm{b}}$ \\
\hline 5 & 29.7 & 325 & 443 & $193,175,160,134$ & Diferuloyl glycerol I & $4.79 \pm 0.03^{\mathrm{a}}$ & $16.32 \pm 0.64^{\mathrm{b}}$ \\
\hline 6 & 30.5 & 312 & 413 & $134,160,193,145,119$ & Coumaroylferuloyl glycerol II & $0.71 \pm 0.05$ & nd \\
\hline \multirow[t]{2}{*}{7} & 30.9 & 324 & 443 & $193,175,160,134$ & Diferuloyl glycerol II & $0.077 \pm 0.01$ & nd \\
\hline & & & & & Total phenolic compounds & $\overline{8.56 \pm 0.13^{a}}$ & $56.93 \pm 0.70^{b}$ \\
\hline
\end{tabular}

In each row different letters mean significant differences $(\mathrm{p}<0.05)$; nd: not detected.
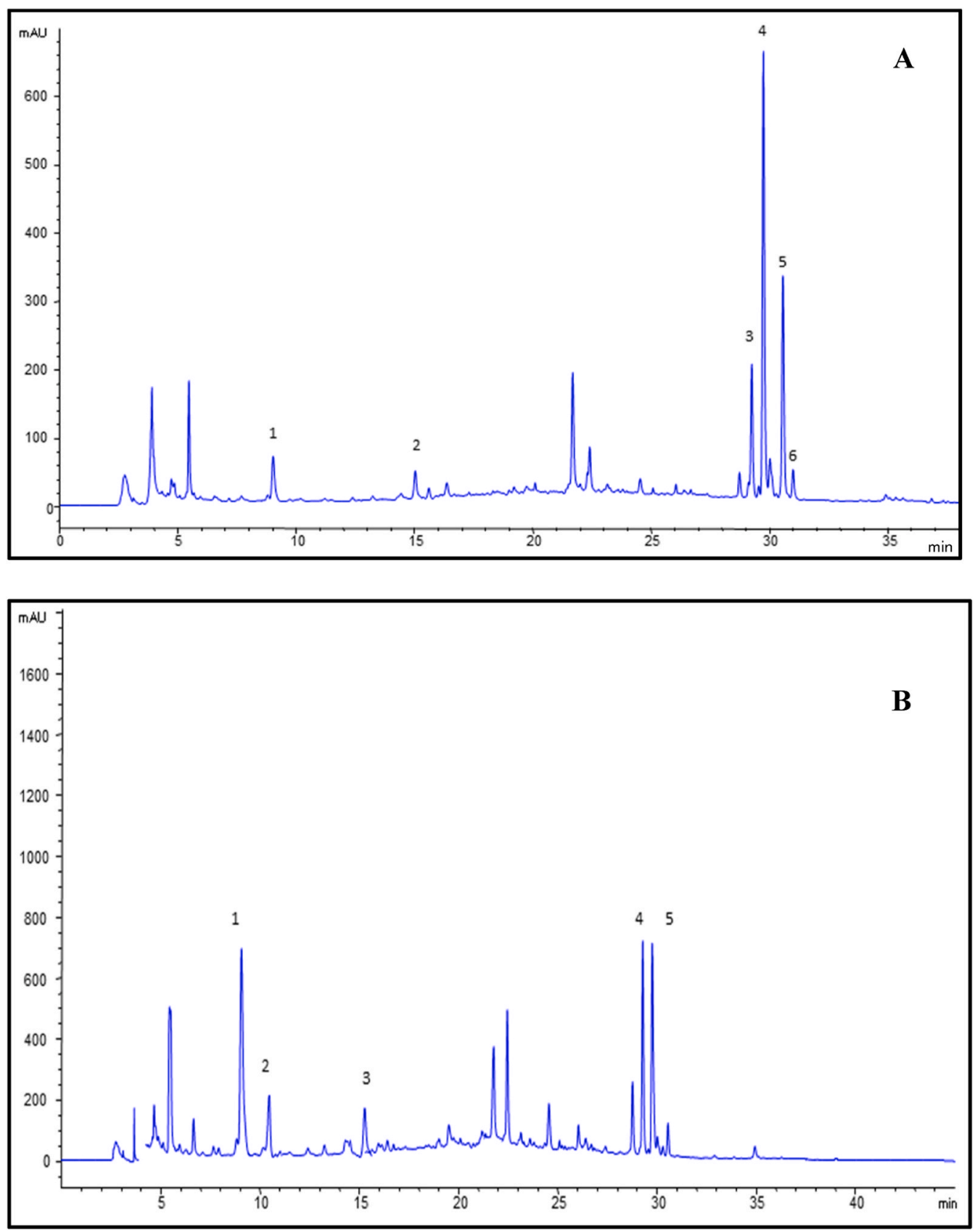

Fig. 1. HPLC-UV (330 nm) chromatogram of the infusions from rhizomes (A) and roots (B) from Asparagus stipularis. 
natural mechanisms of defence against biotic and abiotic stresses, and with relevant biological activities that have been related to human health protection (Quideau et al., 2011). Phenolic compounds have been reported to exhibit antioxidant, inflammatory, antimicrobial, and antiproliferative activities (Ferreira et al., 2017; Santos-Buelga et al., 2019).

HPLC-DAD/ESI-MS analysis was performed to obtain more insights on the phenolic composition of A. stipularis extracts. Peak characteristics, tentative identifications and quantification are presented in Table 6, and exemplificative chromatograms for the extracts of roots and rhizomes are shown in Fig. 1. Seven hydroxycinnamoyl derivatives were detected in both samples. Peak 1 was positively identified as caffeic acid by comparison with a commercial standard, while the remaining compounds were tentatively identified based on their UV and mass spectra characteristics. Compound $2\left([\mathrm{M}-\mathrm{H}]^{-}\right.$at $m / z$ 353) corresponded to a caffeoylquinic acid as shown by the product ions at $\mathrm{m} / \mathrm{z} 179$ (caffeic acid- $\mathrm{H}$ ) and 135 (caffeic acid- $\mathrm{CO}_{2}-\mathrm{H}$ ). The other five compounds were associated to ferulic acid derivatives, supported by the presence of the ion at $m / z 193$ (ferulic acid-H), the presence of cumaroyl moieties in peaks 4 and 6 was confirmed by the ion at $m / z 145$ (coumaric acid- $\mathrm{H}_{2} \mathrm{O}$ $\mathrm{H})$ and the decrease in the maximum UV wavelength approaching to that of coumaric acid $(310 \mathrm{~nm})$. Thus, the following identities were assigned as feruloyl glycerol (compound 3), two diferuloyl glycerol isomers (compounds 5 and 7) and two coumaroyl-feruloyl glycerol isomers (compounds 4 and 6). These compounds and similar MS/MS fragmentation patterns were also reported in the infusion of $A$. stipularis spears previously published (Adouni et al., 2018), and described in green Asparagus (Asparagus officinalis) samples by Jimenez-Sanchez et al. (2016). The phenolic composition profile of both analysed extracts was relatively similar, nevertheless, but with notable quantitative differences (Table 6), with phenolic contents that were approximately seven times higher in roots than the rhizomes $(56.93 \pm 0.70$ vs $8.56 \pm$ $0.13 \mathrm{mg} / 100 \mathrm{~g} \mathrm{dw}$ ).

\subsection{Bioactivity of A. stipularis extracts}

Antioxidant activities should be measured using different methods, with various concepts, applications, mechanisms of action and ways of expressing results (Oliveira et al., 2009). For this reason, the antioxidant activity of $A$. stipularis infusions was determined by DPPH, ABTS scavenging and FRAP assays, and the results were expressed as $\mathrm{EC}_{50}$ values (Table 7). As observed, the roots infusion revealed much higher antioxidant activity in all the different tests than that of the rhizomes $\left(\mathrm{EC}_{50}\right.$ values of $0.44 \pm 0.05 v s 4.70 \pm 0.10$, for $\mathrm{DPPH} ; 0.98 \pm 0.03$ vs $7.38 \pm$ 0.07 , for ABTS and $0.64 \pm 0.05$ vs $7.80 \pm 0.20$, for FRAP). This greater activity could be related to the higher TPC and TFC levels (Table 5) and phenolic contents (Table 6) in the root infusion. Positive correlations between the antioxidant activity of Asparagus species and TFC have been already described in previous studies (Hamdi et al., 2016; Sun et al., 2007). Indeed, it was reported that in green Asparagus, higher phenolic contents were associated to a higher antioxidant capacity (Rodríguez et al., 2005). Furthermore, the greater content in organic acids found in root infusion could also contribute to its higher antioxidant effectiveness compared to rhizomes. The antioxidant potential of distinct organic

Table 7

Antioxidant activity and citotoxicity of Asparagus stipularis infusions.

\begin{tabular}{|c|c|c|}
\hline & $\begin{array}{l}\text { Roots } \\
\text { Infusion }\end{array}$ & $\begin{array}{l}\text { Rhizomes } \\
\text { Infusion }\end{array}$ \\
\hline \multicolumn{3}{|l|}{ Antioxidant activity $\left(\mathrm{EC}_{50}, \mathrm{mg} / \mathrm{mL}\right)$} \\
\hline DPPH scavenging activity & $0.44 \pm 0.005^{\mathrm{a}}$ & $4.70 \pm 0.10^{\mathrm{b}}$ \\
\hline ABTS scavenging activity & $0.98 \pm 0.03^{\mathrm{a}}$ & $7.38 \pm 0.07^{\mathrm{b}}$ \\
\hline Reducing power assay & $0.64 \pm 0.01^{\mathrm{a}}$ & $7.80 \pm 0.20^{\mathrm{b}}$ \\
\hline \multicolumn{3}{|l|}{ Cytotoxicity $\left(\mathrm{GI}_{50}\right.$ value, $\left.\mu \mathrm{g} / \mathrm{mL}\right)$} \\
\hline PLP2 & $>400$ & $>400$ \\
\hline
\end{tabular}

In each row different letters mean significant differences $(\mathrm{p}<0.05)$. acids, for instance, oxalic, malic, citric or succinic acids, has been highlighted by different authors and based on their metal chelating ability (Seabra et al., 2006). Thus, the contribution of organic acids to the antioxidant activity of $A$. stipularis samples cannot be overlooked.

The antioxidant properties of some Asparagus species have been previously demonstrated (Lee et al., 2014; Rodríguez et al., 2005), Nevertheless, the outcomes cannot be compared to those obtained herein due to the differences in the types of assays, extracts and sample preparation and expression of the results.

Regarding cytotoxicity, none of the preparations showed a toxic effect in the porcine liver primary cell culture $\left(\mathrm{GI}_{50}>400 \mu \mathrm{g} / \mathrm{mL}\right.$ ), suggesting that they can be used as safe alternative antioxidant ingredients for medicine or pharmaceutical and food applications.

\subsection{Encapsulation of A. stipularis root extracts into PLGA nanoparticles}

Plant extracts are complex mixtures of chemicals. Yet, their application has been sometimes restricted because of their instability during pharmaceutical and food processing, storage $(\mathrm{pH}$, oxygen, temperature, light) as well as digestion ( $\mathrm{pH}$, enzymes) (Fang \& Bhandari, 2010). Research has been more usually centred on the composition of plant extracts, while solutions that permit their safe, efficient, and direct applications are scarcer. One of the recent ways to overcome some of the outlined limitations is the encapsulation of bioactive compounds into polymeric nanoparticles, to provide protection and allow their delivery in a sustained, controlled or targeted manner (Armendáriz-Barragán et al., 2016). Thus, in the current study, a formulation of PLGA nanoparticles encapsulating the extract of $A$. stipularis root infusion, the most potent of the analysed ones, was developed for potential application in foods, drugs or cosmetics.

\subsubsection{Physicochemical properties of nanoparticles (NPs)}

The particle size, PDI and ZP of the unloaded and loaded prepared NPs are shown in Table 8. Unloaded NPs were produced as controls and their particle size was $243 \pm 4 \mathrm{~nm}$, the PDI around 0.1 and the ZP negative $(-21 \mathrm{mV})$, which are suitable characteristics for compound administration by different paths. The Asparagus-loaded NPs have a slightly higher particle size $(261 \pm 5 \mathrm{~nm})$ than the unloaded ones, which is indicative of the incorporation of the extract into the NPs. Silva et al. (2014) reported particle size values for PLGA 50:50 NPs loaded with phenolic compounds between 140 and $250 \mathrm{~nm}$, whereas Pereira et al. (2015) obtained particle sizes of $300 \mathrm{~nm}$ during the encapsulation of methanol extracts of Lavandula pedunculata and Lavandula stoechas in PLGA NPs. Tachaprutinun et al. (2014) illustrated that NPs with small particle sizes can be suitable pharmaceutical carriers for extracts intended for skin application, as they can easily penetrate intra- and intercellular spaces and through the hair follicles. Pray and Yakine (2009) reported that, when applied with antimicrobial functionality, those NPs do not affect the appearance or texture of food products, as they are invisible to the human eye and cannot be detected in the mouth. Concerning the PDI, which is a dimensionless measure of the broadness of particle size distribution, the results were close to 0.1 for both unloaded and loaded NPs. This result shows a mono- and homogenous dispersity and, consequently, a better particle size distribution (Zigoneanu et al., 2008). As for the ZP, which is the surface charge of the nanoparticles, a value of $-35.9 \pm 0.5 \mathrm{mV}$ was found for loaded NPs. The negative ZP value was due to the presence of terminal carboxylic groups

\section{Table 8}

Average particle size, polydispersity index (PdI), zeta potential (ZP) and encapsulation efficiency (EE) of PLGA nanoparticles (Np) unloaded and loaded with an Asparagus stipularis root infusion extract.

\begin{tabular}{lllll}
\hline & Particle size (nm) & PdI & ZP (mV) & EE (\%) \\
\hline Unloaded PLGA Np & $243 \pm 4$ & $0.11 \pm 0.02$ & $-21 \pm 3$ & \\
Loaded PLGA Np & $261 \pm 5$ & $0.13 \pm 0.02$ & $-35.9 \pm 0.5$ & $83 \pm 3$ \\
\hline
\end{tabular}


in the polymers (Jahan et al., 2015). Klang et al. (2010) suggested ZP of $\pm 30 \mathrm{mV}$ as a standard value for stable nanoemulsions, which ensures a high-energy barrier that stabilizes emulsions. Hence the formulations prepared herein are physically stable with little tendency to particle aggregation.

\subsubsection{Encapsulation efficiency (EE)}

The EE values differ considerably from study to study and many factors influenced them, such as the encapsulated material, the polymer molecular weight as well as the lactide:glycolide ratio (Wischke et al., 2008). In the current study, the EE of Asparagus roots infusion was $82.87 \%$ (Table 8). This value presents a good achievement for plant extracts encapsulated into PLGA in comparison with the literature. The EE value is higher than the previously reported values for PLGA nanoparticles containing plant extracts. Silva et al. (2014) described EE of $1.15 \%$ and $10.61 \%$ for hydroalcoholic extracts of guava and passion fruit encapsulated in PLGA 65:35 NPs and PLGA 50:50 NPs, respectively. EE of 39\% in PLGA 65:35 NPs and of 48\% in PLGA 50:50 NPs were described for cinnamon roots extract by Hill et al. (2013).

\subsubsection{Scanning electron microscopy (SEM)}

Both formulations (unloaded and loaded NPs) were analysed by SEM after freeze-drying with and without trehalose, a classical cryoprotectant. The SEM analysis showed NPs with a spherical morphology and a smooth surface (Fig. 2). Results are in agreement with literature about PLGA NPs (Fonte et al., 2014, 2015). Additionally, the similarity in particle size seen in the SEM analysis was also harmonious, with the physicochemical properties reported in Table 8. As expected, the NPs freeze-dried in the presence of trehalose appear to have a coating that makes them closer, as a slight aggregation, due to the positive cryoprotectant effect of this substance (Fonte et al., 2015).

\subsubsection{Fourier transform infrared (FTIR) spectroscopy analysis}

FTIR spectra of Asparagus roots infusion, physical mixture, PLGA and unloaded nanoparticles (used as controls) and the Asparagus-loaded NPs were performed after freeze-drying and shown in Fig. 3. The PLGA spectrum revealed the appearance of the characteristic peak between 1750 and $1760 \mathrm{~cm}-1$, which matching the $\mathrm{C}=\mathrm{O}$ stretching, and the presence of the peak at $3000 \mathrm{~cm}-1$, corresponding to the $\mathrm{C}-\mathrm{H}$ stretching (Singh et al., 2014). The comparison between the PLGA spectrum and the physical mixture and the NPs spectra indicates a slight deviation to the right at the $\mathrm{C}-\mathrm{H}$ stretching of the PLGA, probably due to the interaction between the PLGA and the other substances. Additionally, the Asparagus-loaded NPs showed not only that deviation but also a rise in the intensity of the same peak, which can be a result of the superimposition of the extract peak at the same wavenumber, as it could be observed in the Asparagus (roots infusion) spectra. It was also important to mention that the Asparagus spectra reveals a peak between 1650 and $1600 \mathrm{~cm}-1$ corresponding to the $\mathrm{C}=\mathrm{C}$ stretching. This peak is also observed in the physical mixture; however, it is not present in the Asparagus-loaded NPs, which may corroborate the efficient encapsulation of the extract.

\subsubsection{Differential scanning calorimetry (DSC) analysis}

The loaded NPs were also evaluated by DSC, as well as the controls (Asparagus roots infusion, PLGA, physical mixture and unloaded NPs), after freeze-drying, and the results are depicted in Fig. 4. The thermograms have a similar melting profile among all samples. Furthermore, the characteristic endothermic peak of PLGA at $48{ }^{\circ} \mathrm{C}$ (Erbetta et al., 2012) was observed in the control samples and in the loaded NPs. Additionally, the Asparagus roots infusion thermogram displayed an exothermic peak at $150{ }^{\circ} \mathrm{C}$, which was not observed in the Asparagus-loaded NPs, probably due to the encapsulation of the extract into the nanoparticles, that stabilizes the systems. This observation also supports the EE results and the physicochemical properties obtained for the nanocarrier.

\section{Conclusions}

The present work provides new information on the nutrient and phytochemical composition of A. stipularis roots and rhizomes. The samples resulted to be a good source of essential and non-essential compounds, such as proteins, lipids, minerals, organic acids and phenolic acids. The evaluation of the antioxidant potential using various in vitro methods demonstrated that the infusion of the roots possessed relevant antioxidant capacity. None of the studied samples was toxic to normal cells. It was also demonstrated that the root infusion extract can be successfully loaded into PLGA nanoparticles. The obtained NPs showed a spherical morphology and high encapsulation efficiency, and the successful loading of the root extract within the developed NPs was also confirmed by FTIR and DSC analysis. The application of nanotechnology could open new perspectives for the potential use of A. stipularis extracts as innovative nutraceuticals. Such nanoparticles produced using plants have been used in various applications for human benefit. Thus, the developed nanoparticles are expected to be used as delivery systems for bioactive compounds of $A$. stipularis and they could be used as an innovative dietary supplement for pharmaceutical and food industry.
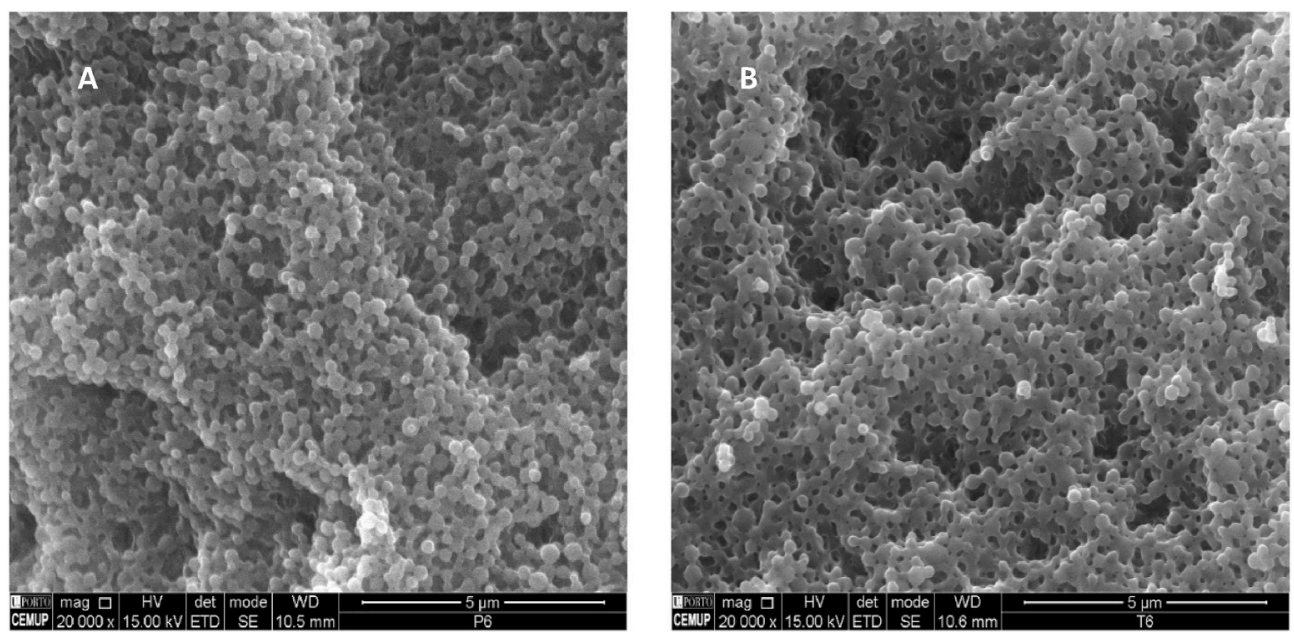

Fig. 2. SEM microphotographs of Asparagus loaded PLGA nanoparticles, after freeze-drying without (A) and with (B) $5 \%$ (w/v) of trehalose, at magnification of $20.000 \times$. The scale bar of the microphotographs at the bottom right of the images corresponds to $5 \mu \mathrm{m}$. 


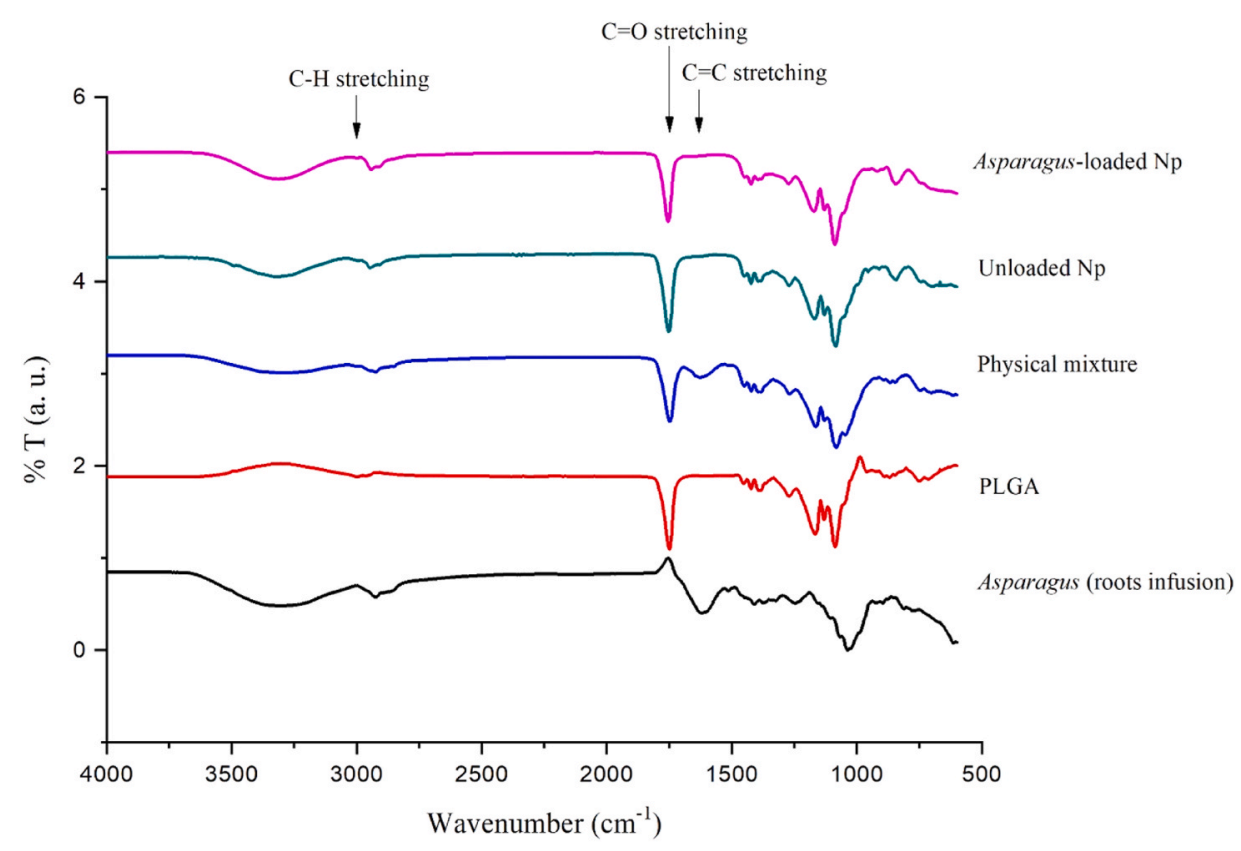

Fig. 3. FTIR spectra of Asparagus (roots infusion), PLGA, physical mixture and unloaded nanoparticles (NP), as controls, and Asparagus-loaded NP after freeze-drying.

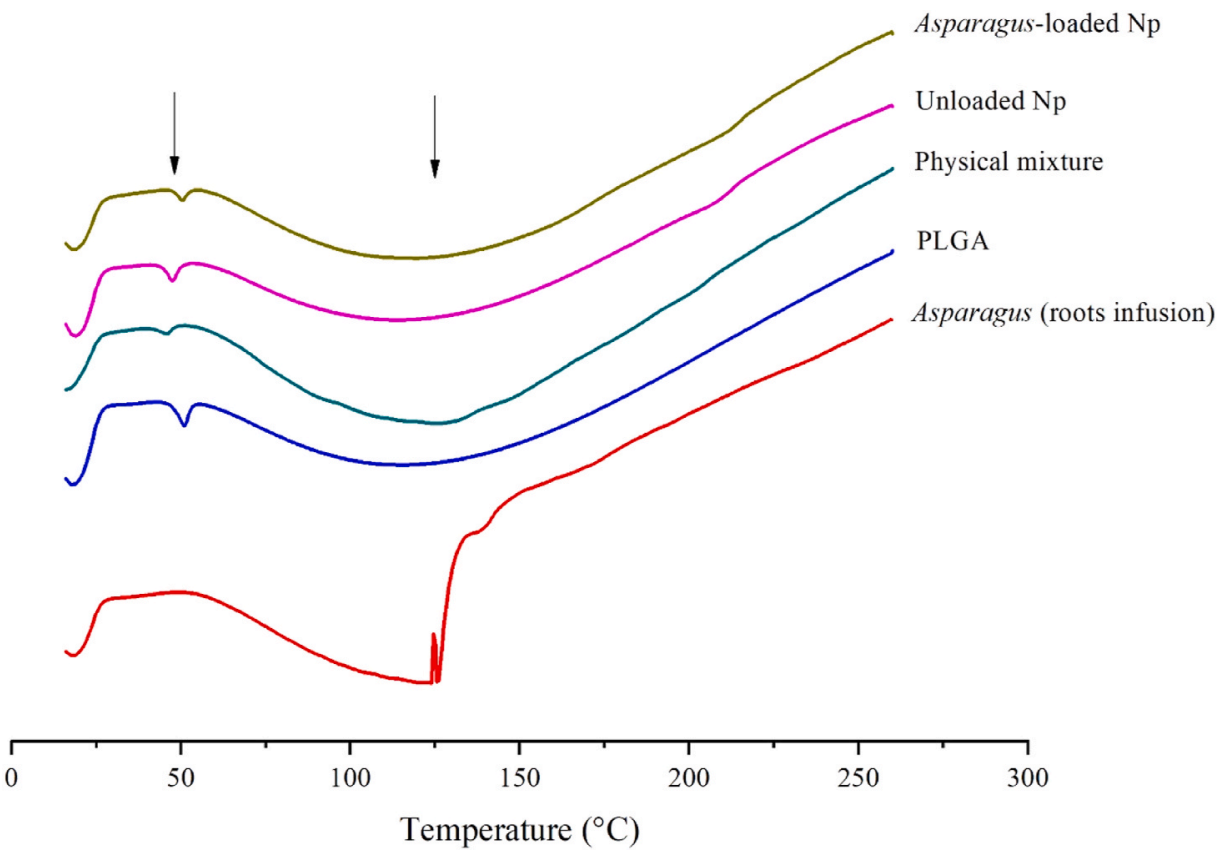

Fig. 4. DSC thermogram of Asparagus (roots infusion), PLGA, physical mixture and unloaded nanoparticles (NP), as controls, and Asparagus-loaded NP after freeze-drying.

\section{Authors' contributions}

Khaoula Adouni was responsible for the collection and preparation of plant materials, performed the experiments, data analysis, and drafted the manuscript; Guido Flamini performed the experiments related to volatile compounds; Ana M. González-Paramás contributed to the HPLC-MS analysis. Ana Júlio and Patrícia Filipe contributed to the FTIR and DSC results and writing the manuscript.

Isabel C.F.R. Ferreira and Ângela Fernandes contributed to the experiments related to tocopherols, organic acids and cytotoxicity; Pedro Fonte, Lotfi Achour, Patricia Morales, Virginia FernándezRuiz, Celestino Santos-Buelga, Patrícia Rijo, Sofia A. Costa Lima and Salette Reis organized this work and contributed to writing the manuscript. All authors read and approved the final manuscript.

\section{Declaration of competing interest}

The authors confirm that they have no conflicts of interest.

\section{Acknowledgments}

The UCM authors would like to thank to ALIMNOVA Research Group (UCM GR105/18) and Spanish Government through the project PID2019-109365RA-I00. Authors are also grateful to Foundation for 
Science and Technology (FCT, Portugal) for financial support through national funds FCT/MCTES to CIMO (UIDB/00690/2020), LAQV (UIDB/50006/2020), CCMar (UIDB/04326/2020), CBIOS (UIDB/ 04567/2020) and iBB-IST (UIDB/04565/2020). A. Fernandes contract was provided by National funding by FCT, P. I., through the institutional scientific employment program-contract. The authors are also grateful to FEDER-Interreg España-Portugal programme for financial support through the project 0377_Iberphenol_6_E. The GIP-USAL is financially supported by the Spanish Government through the project AGL201564522-C2-2-R.

\section{References}

Adouni, K., Zouaoui, O., Chahdoura, H., Thouri, A., Ben Lamine, J., Santos-Buelga, C., González-Paramá, A. M., Maggi, F., Mosbah, H., Haouas, Z., Neffati, F., \& Achour, L. (2018). In vitro antioxidant activity, $\alpha$-glucosidase inhibitory potential and in vivo protective effect of Asparagus stipularis Forssk aqueous extract against highfructose diet-induced metabolic syndrome in rats. J. Funct. Foods, 47, 521-530.

50 AOAC. (2005). Official methods of analysis (18th ed.). Gaithersburg, Maryland: Association of Official Analytical Chemists.

Armendáriz-Barragána, B., Zafar, N., Badri, W., Galindo-Rodrígueza, S. A., Kabbajc, D., Fessib, H., \& Elaissari, A. (2016). Plant extracts: From encapsulation to application. Expert Opinion on Drug Delivery, 13, 1165-1175.

Barros, L., Dueñas, M., Carvalho, A. M., Ferreira, I. C. F. R., \& Santos-Buelga, C. (2012) Characterization of phenolic compounds in flowers of wild medicinal plants from Northeastern Portugal. Food and Chemical Toxicology, 50, 1576-1582.

Benzie, I. F. F., \& Strain, J. J. (1996). The ferric reducing ability of plasma (FRAP) as a measure of 'antioxidant power': The FRAP assay. Analytical Biochemistry, 239, 70-76.

Boulogne, I., Petit, P., Ozier-Lafontaine, H., Desfontaines, L., \& Loranger-Merciris, G. (2012). Insecticidal and antifungal chemicals produced by plants: A review. Environmental Chemistry Letters, 10, 325-347.

Brand-Williams, W., Cuvelier, M. E., \& Berset, C. (1995). Use of a free radical method to evaluate antioxidant activity. Lebensmittel-Wissenschaft und-Technologie-Food Science and Technology, 28, 25-30.

Bremner, P., Rivera, D., Calzadoc, M. A., Obónd, C., Inocencio, C., Beckwitha, C., Fiebiche, B. L., Muñoz, E., \& Heinricha, M. (2009). Assessing medicinal plants from South-Eastern Spain for potential anti-inflammatory effects targeting nuclear factorKappa B and other pro-inflammatory mediators. Journal of Ethnopharmacology, 124, 295-305.

Coimbra, M., Isacchi, B., van Bloois, L., Torano, J. S., Ket, A., Wu, X., Broere, F., Metselaar, J. M., Rijcken, C. J. F., Storm, G., Bilia, R., \& Schiffelers, R. M. (2011). Improving solubility and chemical stability of natural compounds for medicinal use by incorporation into liposomes. International Journal of Pharmaceutics, 416, 433-442.

Danhier, F., Ansorena, E., Silva, J. M., Coco, R., Breton, A. L., \& Préat, V. (2012). PLGA based nanoparticles: An overview of biomedical applications. Journal of Controlled Release, 161, 505-522.

Dhibi, M., Mechri, B., Cheraif, I., \& Hammami, M. (2010). Trans fatty acid isomers in two sesame (Sesamum indicum L.) seed byproducts under processing. Journal of Agricultural and Food Chemistry, 58, 12210-12215.

Dias, M. I., Barros, L., Dueñas, M., Pereira, E., Carvalho, A. M., Alves, R. C., Oliveira, M. B. P. P., Santos-Buelga, C., \& Ferreira, I. C. F. R. (2013). Chemical composition of wild and commercial Achillea millefolium L. and bioactivity of the methanolic extract, infusion and decoction. Food Chemistry, 141, 4152-4160.

EFSA. (2006). European food safety authority. Tolerable upper intake levels for vitamins and minerals. Scientific committee on food. Scientific panel on dietetic products. Nutrition and Allergies, 200.

EFSA. (2015). Scientific opinion in dietary reference values for magnesium. EFSA panel on dietetic products, nutrition and allergies. EFSA Journal, 13, 4186.

El-Seedi, H. R., El-Shabasy, R., Sakr, H., Zayed, M., El-Said, A. M. A., Helmy, K. M. H., Gaara, A. H. M., Turki, Z., Azeem, M., Ahmed, A. M., Boulos, L., Borg-Karlson, A. K., \& Göransson, U. (2012). Anti-schistosomiasis triterpene glycoside from the Egyptian medicinal plant Asparagus stipularis. Brazlian Journal of Pharmacognent, 22, 314-318.

Erbetta, C. D., Alves, R. J., Resende, J. M., de Souza Freitas, R. F., \& de Sousa, R. G. (2012). Synthesis and characterization of poly (D, L-lactide-co-glycolide) copolymer. Journal of Biomaterials and Nanobiotechnology, 3, 208-225.

European Parliament \& Council of the European Union. (2011). Regulation (EU) No 1169/2011 of the European Parliament and of the Council of 25 October 2011 on the provision of food information to consumers. Off. J. Eur. Union, 50, 18-63.

Fang, Z., \& Bhandari, B. (2010). Encapsulation of polyphenols: A review. Trends in Food Science \& Technology, 21, 510-523.

FAO/WHO. (2001). Human Vitamin and Mineral Requirements. Report of a Joint FAO/WHO Expert Consultation, Bangkok (pp. 223-224). Rome: Food and Nutrition Division, FAO.

Ferreira, I. C. F. R., Martins, N., \& Barros, L. (2017). Phenolic compounds and its bioavailability: In vitro bioactive compounds or health promoters? Advances in Food \& Nutrition Research, 82, 1-44.

Fonte, P., Araújo, F., Seabra, V., Reis, S., Van DeWeert, M., \& Sarmento, B. (2015). Coencapsulation of lyoprotectants improves the stability of protein-loaded PLGA nanoparticles upon lyophilization. International Journal of Pharmacy, 496, 850-862.
Fonte, P., Soares, S., Sousa, F., Costa, A., Seabra, V., Reis, S., \& Sarmento, B. (2014). Stability study perspective of the effect of freeze-drying using cryoprotectants on the structure of insulin loaded into PLGA nanoparticles. Journal of Biomacromolecules, 15, 3753-3765.

Fuentes-Alventosa, J. M., Jaramillo- Carmona, S., Rodriguez-Gutierrez, G., RodriguezArcos, R., Fernández-Bolaños, J., Guillén-Bejarano, R., Espejo-Calvo, J. A., \& Jiménez-Araujo, A. (2009). Effect of the extraction method on phytochemical composition and antioxidant activity of high dietary fibre powders obtained from Asparagus by-products. Food Chemistry, 116, 484-490.

Fuentes-Alventosa, J. M., Jaramillo-Carmona, S., Rodríguez-Gutiérrez, G., GuillénBejarano, R., Jiménez-Araujo, A., Fernández-Bolanos, J., \& Rodríguez-Arcos, R. (2013). Preparation of bioactive extracts from Asparagus by-product. FBP, 91, 74-82.

Galala, A. A., Ahmad, K. F., Zaghloul, M. G., \& Mansour, E. S. S. (2015). Two new alkaloids from Asparagus stipularis Forssk. roots. Phytochemical Letters, 12, 220-223.

García-Herrera, P., Morales, P., Fernández-Ruiz, V., Sánchez-Mata, M. C., Cámara, M., Carvalho, A. M., Ferreira, I. C. F. R., Pardo-de-Santayana, M., Molina, M., \& Tardio, J. (2014). Nutrients, phytochemicals and antioxidant activity in wild populations of Allium ampeloprasum L., a valuable underutilized vegetable. Food Research International, 62, 272-279.

Guimarães, R., Barros, L., Duenas, M., Calhelha, R. C., Carvalho, A. M., Santos-Buelga, C., Queiroz, M. J., \& Ferreira, I. C. F. R. (2013). Nutrients, phytochemicals and bioactivity of wild roman chamomile: A comparison between the herb and its preparations. Food Chemistry, 136, 718-725.

Hamdi, A., Jaramillo-Carmonab, S., Beji, R. S., Tej, R., Zaoui, S., Rodríguez-Arcos, R., Jiménez-Araujo, A., Kasri, M., Lachaal, M., Bouraoui, N. K., \& Guillén-Bejarano, R. (2016). The phytochemical and bioactivity profiles of wild Asparagus albus L. plant. Food Research International, 99, 729-729.

Hill, L. E., Taylor, T. M., \& Gomes, C. (2013). Antimicrobial efficacy of poly (DL-lactideco-glycolide) (PLGA) nanoparticles with entrapped cinnamon bark extract against Listeria monocytogenes and Salmonella typhimurium. Journal of Food Science, 78, $626-632$.

Hubert, J., Münzbergová, Z., \& Santino, A. (2008). Plant volatile aldehydes as natural insecticides against stored-product beetles. Pest Management Science, 64, 57-64.

Itoh, T., Nakashima, T., Akamatsu, T., Izu, N., \& Shin, W. (2013). Nonanal gas sensing properties of platinum, palladium, and gold-loaded tin oxide VOCs sensors. Sensors Actuators B-Chemistry, 187, 135-141.

Jahan, S. K., \& Haddadi, A. (2015). Investigation and optimization of formulation parameters on preparation of targeted anti-CD205 tailored PLGA nanoparticles. Internataional Journal of Nanomedicine, 10, 7371-7384.

Jelled, A., Ben Hassine, R., Thouri, A., Flamini, G., Chahdoura, H., El Arem, A., Ben Lamine, J., Kacem, A., Haouas, Z., Ben Cheikh, H., \& Achour, L. (2016). Immature mulberry fruits richness of promising constituents in contrast with mature ones: A comparative study among three Tunisian species. Industrial Crops and Products, 95, 434-443.

Jia, Z., Tang, M., \& Wu, J. (1999). The determination of flavonoid contents in mulberry and their scavenging effects on superoxide radicals. Food Chemistry, 64, 555-559.

Jiménez-Sánchez, C., Lozano-Sánchez, J., Rodríguez-Pérez, C., Segura-Carretero, A., \& Fernández-Gutiérrez, A. (2016). Comprehensive, untargeted, and qualitative RPHPLC-ESI-QTOF/MS2 metabolite profiling of green Asparagus (Asparagus officinalis). Journal of Food Composition and Analysis, 46, 78-87.

Kanno, A., \& Yokoyama, J. (2011). In A. C. Kole (Ed.), Wild Crop Relatives: Genomic and Breeding Resources: Vegetables (pp. 23-42). Springer-Verlag Berlin Heidelberg.

Keiler, A. M., Zierau, O., \& Kretzschmar, G. (2013). Hop extracts and hop substances in treatment of menopausal complaints. Planta Medica, 79, 576-579.

Klang, V., Matsko, N., Zimmermann, A. M., Vojnikovic, E., \& Valenta, C. (2010). Enhancement of stability and skin permeation by sucrose stearate and cyclodextrins in progesterone nanoemulsions. International Journal of Pharmacy, 393, 152-160.

Lee, J. W., Lee, J. H., Yu, I. H., Gorinstein, S., Bae, J. H., \& Ku, Y. G. (2014). Bioactive compounds, antioxidant and binding activities and spear yield of Asparagus officinalis L. Plants. Foods. Human Nutrition, 69, 175-181.

Liu, Q., Tang, G. Y., Zhao, C. N., Gan, R. Y., \& Li, H. B. (2019). Antioxidant activities, phenolic profiles, and organic acid contents of fruit vinegars. Antioxidants, 8, 78.

Lu, W., Kelly, A. L., \& Miao, S. (2016). Emulsion-based encapsulation and delivery systems for polyphenols. Trends in Food Science \& Technology, 47, 1-9.

Mani-Lópeza, E., Garcíaa, H. S., \& López-Malob, A. (2012). Organic acids as antimicrobials to control Salmonella in meat and poultry products. Food Research International, 45, 713-721.

Mechri, B., Tekaya, M., Cheheb, H., \& Hammami, M. (2015). Determination of mannitol, sorbitol and myo-inositol in olive tree roots and rhizospheric soil by gas chromatography and effect of severe drought conditions on their profiles. Journal of Chromatographic Science, 53, 1-7.

Morales, P., Ferreira, I. C. F. R., Carvalho, A. M., Sánchez-Mata, M. C., Cámara, M., Fernández-Ruiz, V., Pardo-de-Santayana, M., \& Tardío, J. (2014). Mediterranean non-cultivated vegetables as dietary sources of compounds with antioxidant and biological activity. Lebensmittel-Wissenschaft und -Technologie- Food Science and Technology, 55, 389-396.

Muller, M., Canfora, E. E., \& Blaak, E. E. (2018). Gastrointestinal transit time, glucose homeostasis and metabolic health: Modulation by dietary fibers. Nutrients, 10(3), 275.

Oliveira, A. C., Valentim, I. B., Goulart, M. O. F., Silva, C. A., Bechara, E. J. H., \& Trevisan, M. T. S. (2009). Fontes vegetais naturais de antioxidantes. Quimica Nova, $32,689-702$

Pegiou, E., Mumm, R., Acharya, P., Vos, R. C. H., \& Hall, R. D. (2019). Green and white Asparagus (Asparagus officinalis): A source of developmental, chemical and urinary intrigue. Metabolites, 10, 2-23. 
Pereira, F., Baptista, R., Ladeiras, D., Madureira, A. M., Teixeira, G., Rosado, C., Fernandes, A. S., Lia, A., Oliveira Silva, C., Pinto Reis, C., \& Rijo, P. (2015) Production and characterization of nanoparticles containing methanol extracts of Portuguese lavenders. Measurement, 74, 170-177.

Pereira, C., Barros, L., Carvalho, A. M., \& Ferreira, I. C. F. R. (2013). Use of UFLC-PDA for the analysis of organic acids in thirty-five species of food and medicinal plants. Food Analytical Methods, 6, 1337-1344.

Petropoulos, S. A., Pereira, C., Ntatsi, G., Danalatos, N., Barros, L., \& Ferreira, I. C. F. R. (2017). Nutritional value and chemical composition of Greek artichoke genotypes. Food Chemistry, 267, 296-302.

Pray, L. A., \& Yakine, A. L. (2009). Nanotechnology in food products: Workshop summary. Washington: D.C. Natl. Academy Press.

Puntarulo, S. (2005). Iron, oxidative stress and human health. Molecular Aspects of Medicine, 26, 299-312.

Quideau, S., Deffieux, D., Douat-Casassus, C., \& Pouysegu, L. (2011). Plant polyphenols: Chemical properties, biological activities and synthesis. Angewandte Chemie International Edition, 50, 586-621.

Re, R., Pelligrini, N., Proteggente, A., Pannala, A., Yang, M., \& Rice-Evans, C. (1999). Antioxidant activity applying an improved ABTS radical cation decolorization assay. Free Radical Biology and Medicine, 26, 1231-1237.

Ribeiro, A. F., Torres, C., Ferreira, G., Santos, J. F. D., Cabral, L. M., \& Sousa, V. P. D. (2015). Design of experiments for the developement $\mathrm{f}$ poly (D, L-lactide-coglycolide) nanoparticules loaded with Uncaria tomentosa. Journal of Nanoparticle Research, 69, 2-16.

Rodríguez, R., Jaramillo, S., Rodríguez, G., Espejo, J. A., Guillén, R., FernándezBolaños, J., Heredia, A., \& Jiménez, A. (2005). Antioxidant activity of ethanolic extracts from several Asparagus cultivars. Journal of Agricultural and Food Chemistry, $53,5212-5217$.

Sánchez-Mata, M. C., Cabrera-Loera, R. D., Morales, P., Fernández-Ruiz, V., Cámara, M., Díez-Marqués, C., Pardo-de-Santayana, M., \& Tardío, J. (2012). Wild vegetables of the Mediterranean area as valuable sources of bioactive compounds. Genetic Resources and Crop Evolution, 59, 431-443.

Santos-Buelga, C., González-Paramás, A. M., Oludemi, T., Ayuda-Durán, B., \& GonzálezManzano, S. (2019). Plant phenolics as functional food ingredients. Advances in Food \& Nutrition Research, 90, 183-257.

Seabra, R. M., Andrade, P. B., Valentão, P., Fernandes, E., Carvalho, F., \& Bastos, M. L (2006). Antioxidant compounds extracted from several plant materials. In M. Fingerman, \& R. Nagabhushanam (Eds.), Biomaterials from aquatic and terrestrial organisms (pp. 115-174). Enfield (New Hampshire), Science Publishers.

Serairi-Beji, R., Aidi Wannes, W., Hamdi, A., Tej, R., Ksouri, R., Saidani-Tounsi, M., Lachaal, M., \& Karray-Bouraoui, N. (2017). Antioxidant and hepatoprotective effects of Asparagus albus leaves in carbon tetrachloride-induced liver injury rats. Journal of Food Biochemistry, 42, 1-11.

Silva, T., Pokhrel, L. R., Dubey, B., Tolaymat, T. M., Maier, K. J., \& Liu, X. (2014). Particle size, surface charge and concentration dependent ecotoxicity of three organo-coated silver nanoparticles: Comparison between general linear modelpredicted and observed toxicity. The Science of the Total Environment, 968-976.

Simopoulos, A. P. (1997). Essential fatty acids in health and chronic disease. Food Reviews International, 13, 623-631.
Singh, G., Kaur, T., \& Ravinder, K. A. (2014). Recent biomedical applications and patents on biodegradable polymer-PLGA. International Journal of Pharmacy and Pharmaceutical Sciences, 1, 30-42.

Slatnar, A., Petkovsek, M., Stampar, F., Veberic, R., Horvat, J., Jakse, M., \& Sircelj, H. (2018). Game of tones: Sugars, organic acids, and phenolics in green and purple Asparagus (Asparagus officinalis L.) cultivars. Turkish Journal of Agriculture and Forestry, 42, 55-66.

Stevanovic, M. M., \& Uskokovic, D. P. (2009). Poly (lactide-co-glycolide)-based micro and nanoparticles for the controlled drug delivery of vitamins. Current Nanoscience, $1 \mathrm{e} 14$.

Suman, S. T., \& Gupta, R. (2013). Development of herbal biodegradable polymeric nanoparticle from Clerodendrum infortunatum L. Journal of Bionanoscience, 7 , 341-347.

Sun, T., Tang, J., \& Powers, J. R. (2007). Antioxidant activity and quality of Asparagus affected by microwave-circulated water combination and conventional sterilization, Food Chemistry, 100, 813-819.

Tachaprutinun, A., Meinke, M. C., \& Richter, H. (2014). Comparison of the skin penetration of Garcinia mangostana extract in particulate and non-particulate form. European Journal of Pharmaceutics and Biopharmaceutics, 86, 307-313.

Trumbo, P., Schlicker, S., Yates, A. A., \& Poos, M. (2002). Dietary reference intakes for energy, carbohydrate, fiber, fat, fatty acids, cholesterol, protein and amino acids. Journal of the American Dietetic Association, 102, 1621-1630.

Ulukapi, K., Nasircilar, A. G., Onus, A. N., \& Baktir, I. (2014). In vitro propagation and determination of the nutrient content of naturally grown Asparagus stipularis forssk. Archives of Biological Sciences, 66, 1333-1338.

Wannamethee, S. G., Whincup, P. H., Thomas, M. C., \& Sattar, N. (2009). Associations between dietary fiber and inflammation, hepatic function, and risk of type 2 diabetes in older men: Potential mechanisms for the benefits of fiber on diabetes risk. Diabetes Care, 32, 1823-1825.

Weickert, M. O., \& Pfeiffer, A. F. H. (2018). Impact of dietary fiber consumption on insulin resistance and the prevention of type 2 diabetes. Journal of Nutrition, 148, $7-12$.

Whysner, J., \& Williams, G. M. (1996). D-limonene mechanistic data and risk assessment: Absolute species-specific cytotoxicity, enhanced cell proliferation, and tumor promotion. Pharmacology \& Therapeutics, 71, 127-136.

Wischke, C., \& Schwendeman, S. P. (2008). Principles of encapsulating hydrophobic drugs in PLA/PLGA microparticles. International Journal of Pharmacy, 364, 298-327.

Wolfe, K., Wu, X., \& Liu, R. H. (2003). Antioxidant activity of apple peels. Journal of Agricultural and Food Chemistry, 51, 609-614.

Woranuch, S., \& Yoksana, R. (2013). Eugenol-loaded chitosan nanoparticles: II. Application in bio-based plastics for active packaging. Carbohydrate Polymers, 96, $586-592$.

Zhang, J., Zhang, F., Li, D., Liu, Y., Liu, B., \& Meng, X. (2020). Characterization of metabolite profiles of white and green spears of Asparagus officinalis L. from Caoxian, East China. Food Research International, 128, 108869.

Zigoneanu, I. G., Astete, C. E., \& Sabliov, C. M. (2008). Nanoparticles with entrapped $\alpha$-tocopherol: Synthesis, characterization, and controlled release. Nanotechnology, 19, Article e105606. 